\title{
Do External Auditors Perform a Corporate Governance Role in Emerging Markets? Evidence from East Asia
}

\author{
By: Joseph P. H. Fan and T. J. Wong
}

William Davidson Working Paper Number 400

October 2001 


\title{
Do External Auditors Perform a Corporate Governance Role in Emerging Markets? Evidence from East Asia*
}

\author{
Joseph P. H. Fan and T.J. Wong ${ }^{\mathrm{b}}$ \\ ${ }^{a}$ Department of Finance, School of Business and Management, The Hong Kong \\ University of Science and Technology, Clear Water Bay, Hong Kong, Tel.: +852-2358- \\ 8016, Email Address: pjfan@ust.hk. \\ ${ }^{b}$ Department of Accounting, School of Business and Management, The Hong Kong \\ University of Science and Technology, Clear Water Bay, Hong Kong, Tel.: +852-2358- \\ 7574, Email Address: actjwong@ust.hk.
}

This version: October 2001

\begin{abstract}
In emerging markets, the concentration of corporate ownership has created agency conflicts between controlling owners and minority shareholders. Conventional corporate control mechanisms such as boards of directors and takeovers are typically weak in containing the agency problem. This study examines whether external independent auditors could be employed as monitors and as bonding mechanisms to alleviate the agency conflict. Using a broad sample of firms from eight East Asian economies, we document that firms are more likely to employ Big Five auditors when they are more subject to the agency problem imbedded in their ultimate ownership structure. One possible reason that this documented relation between auditor choice and the agency problem is more evident than the inconsistent results using U.S. and U.K. data is that alternative governance mechanisms are limited in East Asia. In addition, among East Asian auditees subject to the agency problem, Big Five auditors charge a higher fee and set a lower audit modification threshold while non-Big Five auditors do not. Taken together, the evidence suggests that Big Five auditors in emerging markets do have a corporate governance role.

Keywords: Corporate Governance, Auditor, Ownership Concentration, East Asia

*We appreciate helpful comments from Sugato Bhattacharyya, Nick Dopuch, Masaharu Hanazaki, Clive Lenox, Harold Mulherin, Bob Roussey, Steve Taylor, and workshop participants at Hitotsubashi University, the Hong Kong University and Science and Technology, INSEAD, Shanghai University of Finance and Economics, University of Queensland, and University of Technology - Sydney, and conference participants at the 2001 International Symposium on Auditing Research, the Third Annual Conference on Financial Market Development in Emerging and Transition Economies, the 2001 Asian Pacific Finance Association Conference, and the 2001 European Finance Association Annual Conference. T.J. Wong acknowledges the financial support of the Wei Lun Fellowship.
\end{abstract}




\title{
Do External Auditors Perform a Corporate Governance Role in Emerging Markets? Evidence from East Asia*
}

\author{
Joseph P. H. Fan and T.J. Wong
}

\section{Non-technical Summary}

Since the 1997 financial crisis, East Asian governments and international organizations have made efforts to reform corporate governance. Notwithstanding new laws and regulations, theory suggests that entrepreneurs requiring external capital would have incentives to mitigate their agency problems by introducing monitoring and/or bonding mechanisms. They would voluntarily tie their hands when the expected benefit of the external financing exceeds the expected gain from expropriating outside investors. In particular, the entrepreneurs may voluntarily employ reputation intermediaries to assure outside investors about their credibility. In this paper, we investigate whether independent external auditors can serve a corporate governance role by testifying the quality of accounting information. The appointment of quality auditors serves as an assurance to the investors that the companies' financial disclosures would be accurate and truthful. The assurance is credible because the auditors, with their reputation at stake, will closely scrutinize their clients' books and truthfully disclose their findings.

However, whether or not East Asian auditors in practice fulfill the quality assurance role and hence mitigate the agency problem has been a subject of debate. On the one hand, compared with external auditors in the U.S. and U.K., auditors in East Asia potentially have a stronger governance role because East Asian legal systems and the other conventional corporate control systems are weaker in protecting investors. This is supported by the fact that in East Asia, with the presence of Big Five accounting firms and other international firms, the market for external auditors is 
much more vibrant than the market for takeovers or independent directors. On the other hand, the relationship-based transactions and the under-development of the domestic accounting profession in East Asia may have considerably reduced the demand and supply of quality audits. Evidence in a United Nations report calls into question if East Asian external auditors actually serve as monitors. The report queries why many external auditors had issued clean auditing opinions to clients that later went bankrupt within a few months after the completion of the audits at the Asian Financial Crisis.

To test whether external auditors perform a governance role, we use a broad sample of East Asian firms to first examine if firms that are more subject to agency conflicts hire "name-brand" (Big Five) auditors. Big Five auditors have international reputations and are generally perceived to be more independent than local auditors. If Big Five auditors provide better quality assurance, the demand for their services should increase in response to clients' agency problems. In contrast, the opposing hypothesis suggests that a firm's choice of auditor is insensitive to its agency problems; a firm may even avoid hiring a Big Five auditor to reduce external monitoring.

To further examine the governance role of East Asian auditors, we investigate if they take into account firms' agency conflicts when making audit pricing and audit opinion decisions. If auditors provide assurance of quality through their superior reputations or if they exert efforts to mitigate agency conflicts, these additional services would be reflected in the audit fee. Thus, we test if ceteris paribus auditors charge a premium in response to agency problem. Finally, we test if poor earnings would more likely trigger East Asian auditors to issue modified opinions to firms subject to large agency problems than to those subject to small agency problems. The 


\section{William Davidson Institute Working Paper 400}

loss exposure associated with firms' agency problems per se may be insignificant, but it will be magnified when the firms are in financial distress. Thus, if auditors provide quality assurance, they will consider the increased risk exposure associated with the agency problems and thus give more modified opinions to poorly performing clients with large agency problems.

We find that in East Asia, firms subject to large agency conflicts, indicated by their high control concentration and a large separation of control and ownership, are more likely to hire Big Five auditors than firms less subject to agency problem. We further find that the auditee's ownership structure is associated with its choice of auditor only among small and high-risk auditees, whose threat of expropriation by ultimate owners is high, but not among large and low risk auditors whose threat of expropriation is low. Our results also show that Big Five auditors take into consideration their auditees' ownership structure when making pricing and opinion decisions, while non-Big Five auditors do not. More specifically, Big Five auditors charge clients with controlling owners who enjoy effective control but actually own a small stake in the firm a premium. Lastly, we document that poor earnings can more likely trigger a modified opinion about Big Five clients with large agency problems, which suggests that Big Five auditors lower the modification threshold as their clients' agency problems increase. The overall evidence lends support to the agency theory and suggests that auditors play a crucial monitoring role to mitigate agency problems in emerging markets.

This paper contributes to the corporate governance literature by linking the corporate ownership structure with mandatory external audits in the context of emerging markets. It provides evidence of how agency conflicts between majority and minority shareholders affect the choice of auditors, and the auditing fees and 
auditing opinions of the auditor. Auditor types, fees and opinions provide quantifiable measures of the quality of this corporate governance mechanism. From the policy perspective, this study sheds light on the question of whether voluntary governance mechanisms were at work prior to the Asian Financial Crisis. 


\section{Introduction}

Agency problem of listed companies in East Asia is closely related to their concentrated ownership structure. Tight control creates entrenchment problem: controlling owners' corporate decisions, when against the interests of minority shareholders, are not easily contestable by internal and external control systems, i.e., boards of directors and takeover markets, respectively. Moreover, the controlling owners often leverage up their control by means of stock pyramids and cross shareholdings. ${ }^{1}$ The separation of control (voting rights) from ownership (cash flow rights) exacerbates the controlling owners' incentive to hold up minority shareholders. However, the companies and the controlling owners ultimately have to bear the cost: their shares would be traded at discounts as outside investors anticipate the agency problem (Claessens et al., forthcoming; La Porta et al., 2000). The agency problem has also been attributed as a key factor that exacerbated the stock market declines in East Asia during the 1997 financial crisis (Johnson et al., 2000; Mitton, 2001; Lemmon and Lins, 2001).

Since the financial crisis, East Asian governments and international organizations (World Bank and International Monetary Fund) have made efforts to reform corporate governance. Notwithstanding new laws and regulations, theory suggests that entrepreneurs requiring external capital would have incentives to mitigate their agency problems by introducing monitoring and/or bonding mechanisms (Jensen and Meckling, 1976). They would voluntarily tie their hands when the expected benefit of the external financing exceeds the expected gain from expropriating outside investors. In particular, the entrepreneurs may voluntarily employ reputational intermediaries to assure outside investors about their credibility. In this paper, we investigate whether independent external auditors can serve a corporate governance role by 
testifying the quality of accounting information. The appointment of quality auditors serves as an assurance to the investors that the companies' financial disclosures would be accurate and truthful. The assurance is credible because the auditors, with their reputation at stake, will closely scrutinize their clients' books and truthfully disclose their findings.

We focus on the auditors' role in safeguarding accounting information, because correct accounting information endorsed by reputable auditors is a critical governance constraint that limits controlling owners' ability to steal. On the contrary, if the auditors fail to perform, the controlling owners would have a higher degree of freedom to manipulate accounting information to cover up their self-dealings.

However, whether or not East Asian auditors in practice fulfill the quality assurance role and hence mitigate the agency problem has been a subject of debate. On the one hand, compared with external auditors in the U.S. and U.K., auditors in East Asia potentially have a stronger governance role because East Asian legal systems and the other conventional corporate control systems are weaker in protecting investors. This is supported by the fact that in East Asia, with the presence of Big Five accounting firms and other international firms, the market for external auditors is much more vibrant than the market for takeovers or independent directors. On the other hand, as will be discussed further in the next section, the relationship-based transactions and the under-development of the domestic accounting profession in East Asia may have considerably reduced the demand and supply of quality audits. Evidence in a United Nations report (Rahman, 1999) calls into question if East Asian external auditors actually serve as monitors. The report queries why many external auditors had issued clean auditing opinions to

${ }^{1}$ There is a growing body of literature documenting that the separation of ownership and control is common among public corporations around the world. La Porta et al. (1999) report such evidence for more than 600 corporations in 27 developed countries. Claessens, Djankov, and Lang (2000) report similar evidence in East Asia. 
clients that later went bankrupt within a few months after the completion of the audits at the Asian Financial Crisis.

To test whether external auditors perform a governance role, we use a broad sample of East Asian firms to first examine if firms that are more subject to agency conflicts hire "namebrand" (Big Five) auditors. Big Five auditors have international reputations and are generally perceived to be more independent than local auditors. ${ }^{2}$ If Big Five auditors provide better quality assurance, the demand for their services should increase in response to clients' agency problems. In contrast, the opposing hypothesis suggests that a firm's choice of auditor is insensitive to its agency problems; a firm may even avoid hiring a Big Five auditor to reduce external monitoring.

To further examine the governance role of East Asian auditors, we investigate if they take into account firms' agency conflicts when making audit pricing and audit opinion decisions. If auditors provide assurance of quality through their superior reputations or if they exert efforts to mitigate agency conflicts, these additional services would be reflected in the audit fee. Thus, we test if ceteris paribus auditors charge a premium in response to agency problem. Finally, we test if poor earnings would more likely trigger East Asian auditors to issue modified opinions to firms subject to large agency problems than to those subject to small agency problems. The loss exposure associated with firms' agency problems per se may be insignificant, but it will be magnified when the firms are in financial distress. Thus, if auditors provide quality assurance, they will consider the increased risk exposure associated with the agency problems and thus give more modified opinions to poorly performing clients with large agency problems.

\footnotetext{
${ }^{2}$ Prior research such as Teoh and Wong (1993) and DeFond and Jiambalvo (1993) has documented using U.S. data that Big Five auditors provide better quality service than non-Big Five auditors. In Asia, there is very little research providing direct evidence that Big Five auditors are superior. However, several studies, such as Simon, Ramanan, and Dugar (1986), Simon, Teo, and Trompeter (1992), and DeFond, Francis, and Wong (2000), have documented the existence of a Big Five brand-name fee premium in Hong Kong, Singapore and India, which is consistent with prior research on U.S. firms that Big Five auditors are quality-differentiated from non-Big Five auditors in these Asian countries.
} 


\section{William Davidson Institute Working Paper 400}

To proxy for the extent of the agency problem in East Asian firms, we use the controlling owner's control level and the extent to which the control exceeds the actual corresponding portion of ownership. We expect that the most serious agency problem will occur among firms whose owners possess high degrees of control but own only small stakes in the firms.

The results suggest that external auditors do perform a governance role in East Asia. In the choice of auditors, we find that firms are more likely to hire Big Five auditors when their ownership structure indicates agency conflicts, i.e., when their ultimate owners possess high control but own only small stakes in the firms. Moreover, we find that firms with large agency problems do not hire more non-Big Five auditors. Further tests reveal that the relation between auditor choice and ownership structure exists among small and high leverage firms whose controlling owner entrenchment problem is likely to be magnified by their higher risk, but not among large and low leverage firms whose controlling owner entrenchment problem is likely be less acute. Our results also show that Big Five auditors charge a higher fee and set a lower audit modification threshold to auditees with larger agency problems, while non-Big Five auditors do not. More specifically, Big Five auditors charge a fee premium to clients with high control concentration and large divergence of control and ownership. Also, we document that poor earnings are more likely to trigger modified opinions for Big Five clients with larger agency problems than those with less severe agency problems. Taken together, the evidence suggests that Big Five auditors indeed have monitoring and bonding effects as predicted by the agency theory.

This paper proceeds as follows. Section 2 reviews the literature, discusses the two competing views about the governance role of auditors in East Asia, and presents our 
hypotheses. Section 3 presents the sample data and Section 4 reports the empirical analyses. In Section 5, we conclude the paper.

\section{Development of hypotheses}

In this section we review the literature on auditors' role in corporate governance. We discuss two competing views regarding whether independent external auditors serve such a role in East Asia. We develop several hypotheses pertaining to how auditor choice, audit fee, and audit opinions might reflect East Asian firms' agency problems imbedded in their ownership structures.

\subsection{The positive view}

There has been a long-standing interest in the accounting and finance literatures in examining how firms employ monitors and bonding mechanisms that mitigate agency conflicts between firm managers and outside shareholders (Jensen and Meckling, 1976). Titman and Truement (1986) have a model showing that an entrepreneur that has decided to bring his firm public can choose a higher-quality auditor or investment banker to provide investors information about the firm's true value. Hiring independent external auditors to assure information quality is not a new idea though. Using a historical perspective, Watts and Zimmerman (1983) document that independent audits were demanded since the days of English merchant guilds in the eleventh century to the time when audits were required by law in the twentieth century. Not only is an external audit valued and thus demanded in the absence of law, there is evidence that firms with agency problems are more likely to demand external audits. Chow (1982) uses a sample of U.S. companies from the 1926 Poor's Industrial Manual and documents that large size firms with high debt-equity ratios and many accounting-based debt covenants are more likely to hire 
external auditors. The issue of employing external audit to improve accounting information quality has been more extensively discussed after the recent Securities Exchange Commission pronouncement on Audit Committee Disclosure suggesting that firms that have weak corporate governance mechanisms engage in more earnings management activities. In the U.S., managers have incentives to manage earnings to meet earnings targets in their compensation contracts (Healy, 1986). There has been recent research documenting that earnings management activities are negatively associated with board independence (Klein, 2000b and Peasnell et al., 2000) and the choice of Big Five auditors (Becker et al., 1998).

There have been several U.S. studies that examine auditor choice and the agency problem in more recent periods when external audits were required by law (Palmrose, 1984; Simunic and Stein, 1987; Francis and Wilson, 1988; Eichenseher and Shield, 1989; DeFond, 1992). The common theme of these studies is the linking of auditor choice or switches with the level and/or changes in firm size, leverage and management ownership. These studies find that large firms hire large and/or name-brand auditors. They fail to find that a firm's auditor choice is related to agency problems as measured by management ownership and leverage. However, Deli and Gillan (2000) report that agency problem is relevant in the composition of audit committees in boards of directors. They find that the likelihood of a firm having a fully independent and active audit committee is negatively related to managerial ownership and positively related to leverage.

One possible explanation for the lack of evidence detailing a relation between the agency problem and auditor choice in the recent U.S. studies is that a wide spectrum of corporate governance mechanisms exist in the U.S. that could be employed to alleviate agency conflicts. The idea that other governance mechanisms can serve as substitutes for external auditing is consistent with the assertion of the U.S. Blue Ribbon Committee on Improving the Effectiveness 
of Corporate Audit Committees that auditing is but one piece of the firm's overall corporate governance. Also, Klein (2000a) empirically documents that firms' audit committee independence is negatively associated with their choice of other corporate governance mechanisms.

In contrast with U.S. and U.K. corporations that are typically diffusely owned, the ownership and control of corporations is concentrated in East Asia. When ownership is diffuse as in the U.S. and the U.K., agency problems stem from the conflicts of interest between managers and shareholders. As ownership concentration increases to a level where an owner obtains effective control of the firm, as is the case of East Asia, the nature of agency problems shifts away from manager-shareholder conflicts to conflicts between the controlling owner and minority shareholders (Shleifer and Vishny, 1997). The majority shareholders' ability to effectively control the firm has made conventional corporate governance mechanisms such as corporate takeovers and board of directors ineffective in containing these controlling owners' self-interested activities. In this environment, independent external auditors, especially Big Five firms that follow international auditing practice and draw on expertise internationally, could fill this void in corporate governance and serve as a credible monitor of the controlling shareholders.

In East Asia, external auditors could perform the corporate governance role through limiting the controlling shareholders' ability to manipulate accounting information and hence their ability to extract wealth from outside shareholders. For instance, the controlling owner can manage earnings downward to justify the low cash dividends paid to outside shareholders. The controlling owner can profit from transactions with the firm he/she controls by manipulating accounting numbers to influence the selling or purchase price. Also, many of these transactions are done through a related party. Increasing the disclosure level of related-party activities could 
discourage such self-dealing activities. A typical case is discussed in a recent Asian Wall Street Journal (June 13, 2001) article concerning how the controlling owner of a Korean conglomerate issued low cash dividends and profited from related-party transactions, and the minority shareholders were calling for an extraordinary general meeting to elect an outside independent auditor to monitor the controlling owner.

The corporate governance role of external auditors is frequently discussed in many recent publications by regulators and practitioners in East Asia. For instance, the Securities Exchange Commission of Thailand Corporate Governance Report (1999) argues that transparency is one of the most important aspects of good corporate governance since it allows shareholders to use the disclosed information to monitor the performance of the management. Thus, external auditors could play an important corporate governance role by providing assurance to the accuracy and reliability of financial statements of listed companies. Other publications such as the Asian Corporate Governance Association research report (2000), Corporate Governance 1999 Survey

of Institutional Investors by PricewaterhouseCoopers of Singapore (1999), and the Korean Committee on Corporate Governance report (1999) also highlight the importance of corporate disclosure and transparency, and the role of external audit as part of good corporate governance practice.

\subsection{The negative view}

We have discussed the positive view that auditors in this region could provide quality assurance of accounting information and hence mitigate agency conflicts. On the other hand, a negative view argues that the lack of market demand for and the auditors' willingness to supply quality audits may render it impossible for external auditors to be effective monitors. On the demand side, controlling owners may not desire to hire high quality auditors or even hire low 
quality auditors to reduce external monitoring. Backman (1999) argues that auditing runs against the general culture in Asia where business transactions are relationship based. The idea of needing to monitor and to double-check a company's accounts implies distrust and may lead to open confrontation between owners and investors. Also, political rent seeking is prevalent and highly lucrative in East Asia. Firms in this region may choose to remain opaque in order to prevent competition and/or social sanctions. Even if minority shareholders demand high-quality external audits, they can always be out-voted by the controlling owner. ${ }^{3}$ In addition, investors may question the value of external audits because the rendered opinions by the auditors often do not result in appropriate legal sanctions on firms in emerging markets where law enforcement is weak. On the supply side, the lack of audit expertise and experienced professionals in the local auditing profession weakens auditors' ability to serve as effective monitors. $\$$ Also, their monitoring role may be in conflict with their consulting activities with client firms, an issue not unique to Asia. There has been a growing concern that the lack of disciplinary mechanisms in the auditing profession may have weakened the independence of auditors in Asia.

Consistent with this view, DeFond, Wong, and Li (2000) find that as the Chinese government made efforts to improve auditor independence, domestic firms listed in China took

${ }^{3}$ The audit committees in East Asian Corporations are either non-existent or ineffective, which leaves minority shareholders interests unprotected. In East Asia, only Hong Kong, Singapore and Malaysia view audit committees as a feature of good corporate governance for publicly listed companies. Even if audit committees exist, they often fail to represent the interests of minority shareholders because controlling owners dominate these committees.

${ }^{4}$ The number of CPAs (certified public accountants) and/or CAs (chartered accountants) as a percentage of the population is low among East Asian countries compared with the U.S. (0.1\%), Canada (0.3\%), and Australia $(0.6 \%)$. Except for Hong Kong $(0.2 \%)$ and Singapore $(0.2 \%)$, most other East Asian countries such as Korea $(0.01 \%)$, Indonesia (0.006\%), Malaysia (0.07\%), the Philippines $(0.02 \%)$, and Thailand $(0.008 \%)$ are significantly below the standards of developed economies in regards to the numbers of CPAs and CAs. Schipper (2000) argues that the lack of expertise and professionalism greatly limit the quality of auditors in developing economies.

${ }^{5}$ In economies such as Hong Kong and Malaysia, there have been questions concerning the effectiveness of self-regulation of the accounting profession in the wake of the Asian Financial Crisis (The Hong Kong Economic Journal, April 22, 1999; New Straits Times Press, February 16, 1997). Even in places such as Thailand where the accounting profession is regulated by government, there have been government reports admitting that the monitoring efforts are inadequate (Securities and Exchange Commission of Thailand, 1999). 
flight from high quality to low quality auditors. They document that in 1996, the percentage of modified opinions increased by nine fold after the promulgation of new auditing standards to improve audit quality. However, as audit firms toughen their standards, those that provided high quality monitoring service lost market share to low quality audit firms.

\subsection{Ownership structure as a proxy for agency conflicts}

We use the ownership characteristics of the East Asian firms to capture empirically the extents of their agency problems. Specifically, once obtaining effective contro 6 of the firm, a controlling owner can determine the profit distribution and opportunistically deprive minority shareholders of their rights to share profits. In addition, the controlling owner often secures effective control of the firm through complicated cross shareholdings and stock pyramids. These arrangements enable the controlling owner to command a given level of control while committing a less-than-equivalent ownership. This separation of control and ownership allows controlling owner to extract wealth from the firm, receive the entire benefit, but only bear a much smaller fraction of the cost than when there is no separation of control and ownership. We offer a simple pyramid structure to illustrate this point. A family owns $60 \%$ of the shares of Company A, which in turn owns $40 \%$ of the shares of Company B. As a conservative measure, we say that the family controls $40 \%$ of the voting power in Company B, which is the weakest link in this chain of control rights. However, the family owns only $24 \%$ of the cash flow rights of Company B, which is the product of the two ownership stakes along the chain. Thus, the pyramid exacerbates the agency problem in Company B because every dollar stolen from it costs the family only 24 cents. It will cost the family 40 cents if there is no pyramid and the family's

\footnotetext{
${ }^{6}$ The effective control level is likely affected by the distribution of voting rights which is in turn affected by laws, corporate charters, and ownership dispersion. The level therefore varies across firms and economies. However, Bradley and Kim (1985) show that tender offers are rare when incumbent owners possess more than 20 percent of voting powers.
} 
control level equals its ownership level at $40 \%$. The controlling owner's incentive to expropriate

is expected to increase with the degree of the divergence between the control and the ownership.

\subsection{Hypotheses}

The above discussion suggests that a firm's choice of auditor may or may not affect corporate governance in East Asia. To empirically address this question, we test if firms with large agency problems, proxied by their controlling owners' level of voting rights compared with his/her cash flow rights, would have a larger demand for name-brand (Big Five) auditors who have international reputations and are generally perceived to be more independent. Our formal (alternative) hypothesis is:

H1: A firm's decision to hire a Big Five auditing firm is positively related to its ultimate owner's ability to obtain effective control and/or the degree to which the control exceeds ownership.

If the null is not rejected, it will mean that controlling owners who experience agency conflicts may actually not always hire or even avoid Big Five auditors to evade monitoring.

In addition to examining how agency problems affect firms' choice of auditors, we use audit pricing to measure if auditors charge a fee premium for their clients' agency problems. Again, we use controlling owners' level of separation of ownership and control to proxy for the degree of agency problems. The clients' agency problems may increase auditors' assessment of control risk. Assessed control risk may increase because firms with serious agency problems are likely to have poor management integrity and weak internal controls. This increase in control risk would translate into more audit hours or large risk fee premium, increasing the total audit

${ }^{7}$ Several recent studies have suggested that these ownership characteristics reasonably capture the agency problem in East Asia. Claessens et al. (2000a) report that the divergence between control and ownership rights reduces the value of East Asian firms, which is consistent with the existence of the agency problem. Fan and Wong (2000) report that the credibility of East Asian firms' accounting information decreases with agency conflicts as captured by the firms' ultimate owners' control level and the divergence between their control and ownership rights. 
fee. We therefore test if ceteris paribus East Asian auditors charge their clients who have larger agency problems higher fees. Our formal (alternative) hypothesis is:

H2: The auditing fee charged to a firm is positively related to the firm's ultimate owner's ability to obtain effective control and/or the degree to which the control exceeds ownership.

Prior studies on auditing fees have focused on examining how firm size or brand name (Simunic, 1980; Francis, 1984), industry specialization (Craswell, Francis, and Taylor, 1995; DeFond, Francis, and Wong, 2000), and litigation risk (Clarkson and Simunic, 1994; Simunic and Stein, 1996) affect auditing fees. There have been some recent studies that examine the relation between corporate governance mechanisms and audit fees. Carcello et al. (2000) document that a more independent, diligent, and expert board would demand for more external audit and pay a higher audit fee. However, there may exist some underlying firm characteristics such as management entrenchment problems that raise the demand for high quality board and external audits, causing a spurious correlation. In another study using a sample of 67 Hong Kong listed firms, Gul, Tsui, and Chen (1998) document that family control is associated with lower audit fees. They interpret the result as being consistent with the view that family firms are subject to fewer agency problems than non-family firms. Our study specifically tests if audit pricing is a function of the client firm's agency conflicts between majority and minority shareholders.

Finally, we test if low earnings are more likely to trigger modified opinions by auditors for client firms with larger agency problems than for client firms with smaller agency problems. There are two arguments that support this hypothesis. First, the loss exposure associated with the client firm's agency problems per se may be a small concern when the firm is profitable, but it will become more serious when the firm is in financial distress. When a firm approaches its 
terminal year, the risk of expropriation by its controlling owner increases because the expected penalty if being detected is low. Thus, in bad times, the controlling owner is more prone to engage in self-interested behavior. Second, the controlling owner's entrenchment may weaken the ability of the firm to recover from a hit by poor performance, therefore increasing its bankruptcy risk. Therefore, if auditors serve as external monitors and take into account the risks associated with bankruptcy and controlling owners' entrenchment, they will more likely give modified opinions to poorly performing firms with large agency problems. Our formal (alternative) hypothesis is:

H3: Poor earnings will more likely trigger auditors to issue modified opinions to firms whose ultimate owners possess high degrees of control and achieve the control through less-thanequivalent ownership investment.

\section{Data sample}

Our primary data source is Worldscope. This database contains annual data regarding auditor names, auditing fees, auditing opinions, and financial information for listed companies from over 40 economies around the world. From the database, we select sample firms from eight East Asian economies -- Hong Kong, Indonesia, South Korea, Malaysia, the Philippines, Singapore, Taiwan and Thailand. We select 1994 through 1996 as the period of analysis. We do not include the post-1996 period in our study to avoid possible structural shifts after the 1997 Asian Financial Crisis. We also exclude pre-1994 data because there is too much missing data in this earlier period.

We need to identify the ultimate controlling owners of each firm and what share of the control and ownership rights they hold. For this ownership information, we refer to data 
assembled in Claessens, Djankov, and Lang (2000). Their ownership database traces the complex ownership structure and identify the ultimate controlling owners of about 3,000 publicly traded corporations in nine East Asian economies as of 1996, including the eight economies we selected for study. As the ownership of our sample firms is stable over the sample period, we feel it is reasonable to merge the 1996 ownership data with the 1994-1996 audit and financial data.

\subsection{Basic statistics}

As shown in Table 1, our final sample consists of 3,119 firm year observations from 1994 to 1996. These observations all have auditor, ownership, and financial data that are required for constructing our empirical measures. Our final sample represents $28 \%$ of all the listed companies

in the eight economies ${ }^{8}$ The table shows that Big Five or Big Five-affiliated auditors dominate the auditing activities in the eight economies in our sample. Singapore has the highest percentage of Big Five or Big Five-affiliated auditors with $88.3 \%$, followed by Indonesia with $87.7 \%$, Hong Kong with $80.6 \%$, Malaysia with $74 \%$, Korea with $71.4 \%$, Thailand with $65.3 \%$, the Philippines with $62.3 \%$ and Taiwan has the lowest percentage with $56.1 \%$. In this paper, we do not distinguish between Big Five auditors and Big Five-affiliated auditors. In Indonesia, Korea, the Philippines and Thailand, foreign accounting firms are not permitted to practice without partnering with local firms. All the Big Five auditors in these countries have joined up with large local firms to form Big Five-affiliated firms. The local firms provide valuable business contacts

${ }^{8}$ As in year 1996, the percentages of companies represented in our sample are 37\% for Hong Kong, $47 \%$ for Indonesia, 22\% for Korea, 20\% for Malaysia, 33\% for the Philippines, 56\% for Singapore, 13\% for Taiwan and $18 \%$ for Thailand. 
while the Big Five firms provide technical expertise and their international networks of member firms.

Not all the firms in Worldscope contain audit opinion information. The modified opinion in Worldscope includes disclaimer and adverse opinions, and it does not distinguish among the various types of modified opinion such as asset realization, litigation, and going concern. Combining all these opinions into one should not bias in favor of our second hypothesis. In our sample, only 2,335 firm year observations include an audit opinion. Table 2 presents the percentage of modified opinions by economy and by year in our sample 10 On average, only two percent of the companies in our sample received a modified opinion. The percentage of modified opinions is highest in 1995 and lowest in 1994. In addition, the cross-economy distribution of modified opinions is uneven with Indonesia reporting no modified opinions, while Thailand reported $13.3 \%$ opinions from 1994 to 1996.

Auditing fees are not mandatorily disclosed except in Hong Kong, Malaysia and Singapore. Thus, Worldscope contains auditing fee data only for these three economies in our sample, comprising 1,304 firm year observations. The mean and median auditing fees of the three economies are reported in Table 3. The fee data show that Hong Kong firms spend the most in US dollars (Panel A) and as percentage of assets (Panel B) on auditor services, while Malaysian firms incur the lowest fees for such services.

\subsection{Measuring the ultimate owners' control and ownership levels}

${ }^{9}$ A case in point is the merger of Arthur Andersen and SyCip, Gorres, Velayo and Company (SVG) in the Philippines. SVG was a local firm set up by Washington SyCip in Manila in 1946. During our sample period of 1994 to 1996, Arthur Andersen joined with SVG, which explains why the percentage of market share for Big Five firms increased from $19.2 \%$ to $87.7 \%$ in the Philippines during this period.

${ }^{10}$ For Indonesia, Korea, the Philippines, Taiwan, and Thailand, the standards and format for the audit report generally follow those of the U.S. The standards and reporting format of the audit report in Hong Kong, Malaysia, and Singapore generally follow the international auditing guidelines. 
Most prior studies of ownership structure focus on immediate ownership, which constitutes common shares directly owned by individuals or institutions. Immediate ownership is not sufficient for characterizing the ownership and control structure of East Asian firms, as these firms are often associated with complicated indirect ownership. In contrast to these prior studies, we focus on ultimate ownership as identified in Claessens, Djankov, and Lang (2000). For a given firm, the ultimate owners and their share of control (voting) and ownership (cash flow) rights are identified. To make the distinction between voting and cash flow rights, firmspecific information on pyramid structures and cross-holdings is required.

The procedure for identifying the ultimate owners is similar to the one used by La Porta et al. (1999). An ultimate owner is defined as the shareholder who holds at least $5 \%$ of the voting rights of the company and who is not controlled by anybody else. To economize on the data collection task, tracing further voting control stops at $50 \%$ and the ultimate owner's voting rights level is set equal to $50 \%$ once we reach this level. This ceiling is reasonable because the ultimate owner unambiguously gains full control once $50 \%$ of the voting rights is secured. Although a company can have more than one ultimate owner, we focus on the largest ultimate owner. With the highest level of voting rights, the largest ultimate owner is more likely than smaller owners to be the controlling owner of the firm.

For a given firm, an ultimate owner's voting control level is defined as the ownership stake at the weakest link along the control chains connecting the ultimate owner and the firm. The cash flow rights that support the control by the ultimate owner is the sum of the products of ownership stakes of affiliated firms from each control chain identified.

Consistent with statistics reported by Claessens, Djankov, and Lang (2000) and Fan and Wong (2000), East Asian corporations exhibit high levels of concentration of control in our 
sample: the mean level of voting rights of the ultimate owner is $27 \%$. This is in contrast to U.S. firms studied in most prior research, which are characterized by diffuse ownership and control. The highest mean control concentration is found in Thailand (35\%), followed by Indonesia (34\%), Hong Kong (29\%), and Malaysia (28\%), Singapore (27\%), Taiwan (19\%), and Korea

(17\%). The sample mean cash flowing rights over voting rights $(C V)$ of $87 \%$ indicates that there is a significant degree of divergence between the two rights. The mean $C V$ ratios across the eight economies in ascending order are: Indonesia (79\%), Singapore (82\%), Taiwan (84\%), Malaysia (86\%), Hong Kong (88\%), Korea (89\%), the Philippines (91\%) and Thailand (96\%).

\section{Empirical Analysis}

This section reports the results of our empirical tests on the determination of auditor choice, auditing fees, and auditing opinions.

\subsection{Auditor choice}

We test our first two hypotheses that a firm's choice of auditor is related to the firm's ownership structure using the following pooled cross-sectional LOGIT regression model:

$$
\begin{aligned}
\text { AUDITOR }_{i t}= & a_{0}+a_{1} \log \left(\operatorname{SIZE}_{i t}\right)+a_{2} \text { LEV }_{i t}+a_{3} \text { GROUP }_{i}+a_{4} \text { PYRAMID }_{i}+a_{5} \text { DEV }_{i} \\
& +a_{6} C V_{i}+a_{7} D E V_{i} * C V_{i}+a_{8} \text { fixed effects }+u_{i t}
\end{aligned}
$$

where, for sample firm $i$ and year $t$,

$A U D I T O R=1$ when the auditor is a Big Five (including affiliated) accounting firm, and 0 otherwise;

$S I Z E_{i t}=$ the natural logarithm of total assets in millions of U.S. dollars at year t; 
$L E V_{i t}=$ the long-term debt divided by total assets at year $\mathrm{t}$ (leverage);

$\operatorname{GROUP}_{i}=1$ when the client firm is a member of a corporate group, and 0 otherwise;

$\operatorname{PYRAMID}_{i}=1$ when the client firm is controlled by an affiliated firm through a stock pyramid, and 0 otherwise;

$D E V_{i}=1$ when the percentage of voting rights possessed by the largest ultimate owner of the firm exceeds the median in the corresponding economy, and 0 otherwise;

$C V_{i}=$ the ratio of cash flow rights to voting rights of the largest ultimate owner;

Fixed effects = dummy variables controlling for fixed effects of industries, calendar years and economies;

$u_{i t}=$ error term at year $\mathrm{t}$.

We include total assets and leverage in the model to control for client size and risk. In addition, GROUP and PYRAMID are used as a control for organization complexity. 11 Firms belonging to complex corporate groups are likely to have numerous related-party transactions, which complicate the earnings recognition and accounting consolidation processes. This is particularly the case for firms in the top layers of pyramids that have to incorporate earnings of their affiliated firms on the lower layers of pyramids. $\frac{12}{12}$ We expect that group firms and particularly firms in the top layers of pyramids to have a stronger demand for Big Five auditors. The three ownership variables, $D E V, C V$ and $D E V^{*} C V$ are our experimental variables. $D E V$ is

${ }^{11}$ The information on pyramids is from Claessens, Djankov, and Lang (2000). The group affiliation information is from Claessens et al. (2000), which includes 170 large corporate groups across the eight economies. Firms that are affiliated with small groups, i.e., outside the 170 groups, are treated as independent firms. Firms belonging to the same group do not always hire the same auditor, nor do they always hire auditors in the same class (Big Five or non-Big Five). Each group on average has four member firms (in our final sample) and hires two distinct Big Five auditors and one non-Big Five auditor. Fifty-five of the 170 groups hire at least one Big Five auditor and one non-Big Five auditor among their members.

${ }^{12}$ Except for Korea where consolidation of accounts from subsidiaries is required only in supplementary statements, all other economies in our sample require consolidation in the companies' primary financial statements. 


\section{William Davidson Institute Working Paper 400}

economy wide median adjusted to net out economy level differences in voting control level. To reject the null of $H 1$, we should find that more firms with high control $(D E V=1)$ and/or larger separation of control and ownership $(C V<1)$ hire Big Five auditors. Thus, we expect that the coefficient of $D E V$ is positive, and the coefficients of $C V$ and/or $D E V^{*} C V$ negative.

Before presenting our regression results, we compare each 1996 explanatory variable pooled across all economies for the Big Five and the non-Big Five clients. The results presented in Table 4 show that the control concentration and the divergence between control and ownership rights are statistically significantly higher for Big Five clients than for non-Big Five clients based on the t-test for means and the Wilcoxon signed rank test for medians, supporting the alternative of H1. In addition, there are a higher proportion of Big Five clients belonging to corporate groups based on the mean and median tests, suggesting that the demand for Big Five auditors is associated with group complexity. In terms of client size, Big Five clients have larger mean and median total assets but only the difference in mean is statistically significant. However, leverage and the proportion of firms at the bottom of the pyramids are not statistically different between the two groups.

Table 5 presents the LOGIT regression results estimated for the pooled sample period from 1994 to 1996 and separately in each of the three years. Fixed effects are included in the regressions where appropriate, but for simplicity they are not reported. The pooled time-series results show that large firm and group firms in the upper layers of pyramids are more likely to hire Big Five auditors. Also, $D E V$ is positive and statistically significant, while $D E V * C V$ is negative and statistically significant. This supports the alternative of $H I$ that demand for Big Five auditors is positively associated with the degree of agency problems as captured by the controlling owners' ability to command effective control and the divergence of their control and 
ownership. Similar to the pooled time-series results, the coefficient of $D E V$ is positive and significant, while $D E V^{*} C V$ is negative and statistically significant in the 1994 and 1995 regressions. In the 1996 regression, $C V$ is negative and significant while other ownership variables are not statistically significant. Taking both the pooled time-series and annual regression results together, the evidence is consistent with the alternative of $H 1$ that East Asian firms hire Big Five firms to mitigate their agency conflicts.

To test further the effect of agency conflicts between majority shareholders and minority shareholders on the demand for Big Five auditors, we partition our sample by client size, profit and leverage. For a given ownership structure, we expect that the degree of agency conflicts is more severe in small, low profit, or high leverage firms. The entrenchment problem of the controlling owners is large when the expected loss from being detected is small. Controlling owners of firms that are less established in size or are in financial distress are particularly prone to engage in self-interested behaviors at the expense of outside investors, as their expected loss of reputation and business is low. To be consistent with the monitoring hypothesis, we should find that the hypothesized effects of effective control and divergence between control and ownership rights on auditor choice stronger for small, low profit, or high leverage firms and weaker for larger, more profitable, and low leverage firms.

Table 6 reports the pooled time-series cross-sectional regressions partitioned by client profit, leverage, and size separately. The sample partition is based on the within-economy threeyear medians. For example, client firms are partitioned into the high (low) profit subgroup if their return on assets is higher (lower) than the corresponding three-year median in the economy. The regression presented in Table 5 is re-estimated using the high and low profit subgroups separately. This procedure is repeated for leverage measured by total liability over total assets 
and then for size measured by total assets. The results show that $D E V$ is positive and significant while $D E V^{*} C V$ is negative and significant in the small and the high leverage firms but not in the large and the low leverage firms, while these results are present in both the high and the low profit samples. The evidence in Table 6 supports our prediction that small and high leverage firms tend to have more severe entrenchment problems, and thus their choice of Big Five auditors is more sensitive to their ownership structure. 13

To examine further if the reported effect of the agency problem on the demand for Big Five auditors clusters in particular economies, we re-estimate the LOGIT regression economy by economy. As shown in Table 7, the ownership results are consistent with $H 1$ in several economies, though not clustering in any single economy. The effect of concentration of ownership ( $D E V)$ on the demand for Big Five auditors is positive in Hong Kong, Malaysia, and the Philippines. The effect of $C V$ is negative for Korea, while the joint effect of $D E V$ and $C V$ is negative for Hong Kong, Malaysia and the Philippines. It is interesting to note that the association between our measure of agency conflicts and preference for Big Five auditors is also found in Korea, where there are only Big Five-affiliated auditors, suggesting that Big Fiveaffiliated auditors also provide quality-differentiated audit to mitigate agency problems.

As a diagnostic check, we examine, economy by economy, whether the agency problem affects the choice between non-Big Five auditors and the Big Five auditor that has the largest market share in the economy. The market share of each Big Five auditor is computed based on the auditor's total number of clients divided by the number of listed firms in our sample. ${ }^{14}$ If the

13 Another interpretation for the high leverage sample result is that banks may require their clients with large agency problems to hire more reputable auditors to mitigate their agency problems. Since most long-term debt in East Asia is bank debt, high leverage may be a proxy for this demand from banks.

${ }^{14}$ We also consider Price Waterhouse, and Coopers and Lybrand as two separate firms in this analysis because they are not yet merged into one firm during our sample period. The results of treating these two firms as one or two separate firms are qualitatively similar. 
Big Five market leader commands the best reputation in the economy, excluding Big Five nonmarket leaders from our economy-by-economy regressions would increase the power of the test. This conjecture is confirmed by our results that $D E V$ is positive and significant in all economies in our study but Indonesia, Korea and Thailand, while $D E V^{*} C V$ is negative and significant in all the economies but Indonesia and Thailand. 15 The insignificant results in Indonesia and Thailand are consistent with the null of $H 1$, which suggests that their external auditors may not be fulfilling their monitoring role in these two economies where the demand and supply of good quality auditors are the weakest. 16

In summary, we find that East Asian corporations whose ultimate owners possess high voting control and have a large divergence of control and ownership rights are more likely to employ Big Five auditors. This result supports the view that external auditors play a monitoring and bonding role that mitigates the agency conflicts between controlling owners and outside investors in this region. However, the economy-by-economy results indicate that choice of auditor is insensitive to the agency problem in Indonesia and Thailand, which suggests that external auditors fail to serve as monitors in these two economies.

\subsection{Audit fee}

To test our third hypothesis that the auditing fee reflects a client firm's agency problem, we run the following pooled time-series cross-sectional ordinary least squares regression:

$$
L A F_{i t}=b_{0}+b_{1} \log \left(S I Z E_{i t}\right)+b_{2} R O A_{i t}+b_{3} L E V_{i t}+b_{4} C A C L_{i t}+b_{5} A R_{i t}+b_{6} I N V_{i t}
$$

${ }^{15}$ This result also suggests that the insignificant coefficients of $D E V$ and $D E V^{*} C V$ for Singapore in Table 7 are caused by the weak power of the test. Also, a firm-by-firm check reveals that among the sampled Singaporean firms, 21 firms hire local auditors. Of the 21 firms, 15 firms display control-ownership divergence $(C V<1)$. However, only 6 of the 21 firms display excess control $(D E V=1)$ and only 3 firms display both excess control and control-ownership divergence to the point of serious agency conflicts. These statistics suggest that the overall agency problem of the firms that hire local auditors is not substantial enough to support the null of $H 1$.

${ }^{16}$ A possible alternative explanation is that Big Five auditors are not better in quality in Indonesia and Thailand. 


$$
\begin{aligned}
& +b_{7} \text { GROUP }+b_{8} \text { PYRAMID }+b_{9} D E V_{i}+b_{10} C V_{i}+b_{11} D E V_{i} * C V_{i} \\
& +b_{12} \text { fixed effects }+u_{i t}
\end{aligned}
$$

where, for sample firm $i$ and year $t$,

$L A F_{i t}=$ the natural log of total auditing fees at year $\mathrm{t}$;

$S I Z E_{i t}=$ the natural logarithm of total assets in millions of U.S. dollars at year $\mathrm{t}$;

$R O A_{i t}=$ the net income divided by total assets at year $\mathrm{t}$;

$L E V_{i t}=$ the long-term debt divided by total assets at year $\mathrm{t}$;

$C A C L_{i t}=$ the current assets divided current liabilities at year $\mathrm{t}$;

$A R_{i t}=$ the accounts receivable divided total assets at year $\mathrm{t}$;

$I N V_{i t}=$ inventory divided total assets at year $\mathrm{t}$;

$G R O U P_{i}=1$ when the client firm is a member of a corporate group, and 0 otherwise;

$\operatorname{PYRAMID}_{i}=1$ when the client firm is controlled by an affiliated firm through a stock pyramid, and 0 otherwise;

$D E V_{i}=1$ when the percentage of voting rights possessed by the largest ultimate owner of the firm exceeds the median in the corresponding economy, and 0 otherwise;

$C V_{i}=$ the ratio of cash flow rights to voting rights of the largest ultimate owner;

Fixed effects $=$ dummy variables controlling for fixed effects of industries, calendar years and economies;

$u_{i t}=$ error term at year $\mathrm{t}$.

Consistent with prior studies such as those by Simunic (1980) and Francis (1984), we use a number of variables to control for (1) loss exposure attributable to the audit and (2) loss risk borne 
by the auditor. The level of loss exposure is estimated by total asset size (SIZE), asset composition as measured by the percentage of inventory and accounts receivable in total assets (INV and $A R$ ), and organizational complexity. The literature typically uses the number of domestic and foreign subsidiaries as a proxy for organizational complexity. The information is not available in Worldscope. However, the amount of audit efforts should be associated with two of our organizational complexity variables: corporate group membership (GROUP) and whether the firm is on the bottom of a stock pyramid (PYRAMID). We expect the amount of consolidation work increases when the firm belongs to a corporate group $($ GROUP $=1)$ and is on the top layers of the stock pyramid with many subsidiaries $(P Y R A M I D=0)$. The loss risk borne by the auditor is represented by the auditee's liquidity ratio $(C A C L)$, debt asset ratio $(L E V)$ and profitability $(R O A)$.

Table 8 presents the pooled-economy and the economy-by-economy regression results for Hong Kong, Malaysia and Singapore, where reporting of auditing fees is mandatory. Consistent with prior research, the auditing fee is significantly and positively related to loss exposure and audit risk. More specifically, consistent with the notion that the auditing fee is a function of the complexity of the audit, the coefficients of auditee size, percentage of accounts receivable and inventory in total assets, and group affiliation are positive and statistically significant in the pooledeconomy and economy-by-economy regressions, with the exception that the coefficient of INV, which is not statistically significant for Malaysia, and the coefficient of GROUP, which is not statistically significant for Hong Kong. In addition, audit risk as proxied by auditee's $R O A$ is significantly negatively related to the auditing fee in the pooled-economy regression, as well as in the Hong Kong and Malaysia regressions.

Consistent with $H 2$, we find that the coefficient of $D E V$ is positive and statistically significant and the coefficient of $D E V^{*} C V$ is negative and statistically significant in the pooled 
regression as well as in the Hong Kong and Singapore regressions. When the pooled-economy regression is run separately using Big Five and non-Big Five samples, the coefficient of $D E V$ is positive and the coefficient of $D E V^{*} C V$ is negative in both regressions, but the two coefficients are significant only in the Big Five regression. This suggests that Big Five auditors charge firms with agency problems a premium as captured by the ownership variables, but non-Big Five auditors do not. Thus, pooling Big Five and non-Big Five clients in our regression weakens the ownership results.

We note that the coefficients of $D E V$ and $D E V^{*} C V$ for Malaysia are statistically significant but with opposite signs to those of Hong Kong and Singapore. This suggests that Hong Kong and Singapore auditors charge a premium while Malaysian auditors charge a discount, if the controlling owner of the client firm possesses effective control and has a large divergence between control and ownership. Regulations in the audit market may explain why audit fees in Malaysia fail to reflect agency problems as we predicted. 17 In contrast to Hong Kong and Singapore, where the auditor markets are more internationalized and less regulated, Malaysia has an emerging audit market subject to fee regulations, which may give rise to the different fee structure. There is a smaller presence of Big Five auditors in Malaysia as is evident in our sample in which the average Big Five market share for Malaysia is $74 \%$, which is significantly less than Hong Kong with $80.6 \%$ and Singapore with $88.3 \%$ (Table 1). This lower demand for quality auditors could be driven by the Malaysian government's policies that discourage international investors' involvement in its stock market $\frac{18}{18}$ This is consistent with the

\footnotetext{
${ }^{17}$ Fee regulation is not uncommon in East Asia. The Malaysian Institute of Accountants set fee guidelines for their members. The Korean Institute of Certified Public Accountants also set fee guidelines based on clients' total asset size.

${ }^{18}$ Malaysia has a $30 \%$ limit on the total direct investment by foreign individuals and institutions in a company. Singapore has some limits on foreign direct investment only in strategic industries, while Hong Kong does not have any restrictions. Also, foreign securities firms can only operate as joint venture firms with local partners in Malaysia. There is no such requirement in Hong Kong and Singapore.
} 


\section{William Davidson Institute Working Paper 400}

results in Table 3 that Malaysian corporations incur the least in dollar value and in percentage of total assets of audit fees. Also consistent with the effect of the fee regulation, we find that Big Five auditors charge a fee premium in Hong Kong and Singapore, but not in Malaysia, which is also documented by Simon et al. (1992).

As in the previous auditor choice analysis, we perform further regression analysis of auditing fees using sub-samples partitioned by profit, size, and leverage. In Table 9, we find that the coefficient of $D E V$ is significantly positive for low profit, small, and high leverage clients. The coefficient of $D E V^{*} C V$ is significantly negative in the regressions for small and high leverage clients. In contrast, none of the coefficients of the ownership variables is statistically significantly different from zero for high profit, large, or low leverage clients. Overall, these results are consistent with the hypothesis that auditing fee premiums reflect the degrees of agency conflicts between controlling owners and outside investors.

In summary, the results from the auditing fee analysis show that in Hong Kong and Singapore, auditors, specifically Big Five auditors, charge a premium for clients' agency problems as measured by their ultimate owners' control concentration and separation of control and ownership. This lends further support for the view that auditors play a monitoring role and alleviate agency conflicts in East Asia.

\subsection{Audit opinion}

Finally, to test our last hypothesis that low earnings will more likely trigger a modified opinion for firms with large agency problems than for firms with small agency problems, we run the following pooled time-series cross-sectional LOGIT regression:

OPINION $_{i t}=b_{0}+b_{1} \log \left(S I Z E_{i t}\right)+b_{2} R O A_{i t}+b_{3} L E V_{i t}+b_{4} C A C L_{i t}+b_{5} A R_{i t}+b_{6} I N V_{i t}$ 


$$
\begin{aligned}
& +b_{7} \text { GROUP }+b_{8} \text { PYRAMID }+b_{9} D C V_{i}+b_{10} D C V_{i} * R O A_{i t} \\
& + \text { fixed effects }+u_{i t}
\end{aligned}
$$

where, for sample firm $i$ and year $t$,

$O P I N I O N_{i t}=1$ when it is a modified opinion, and 0 otherwise;

$D C V_{i t}=1$ when the ultimate control exceed ownership rights, and 0 otherwise;

and the other variables are defined earlier.

In this analysis, we use only a dummy variable, $D C V$, to capture agency conflicts. As there are totally only 49 modified opinions in the sample, employing both of the ownership variables is implausible. We also do not include lagged opinions as independent variable because that would further reduce the number of modified opinions in each of our sample years.

The regression results presented in Table 10 suggest that the modified opinions are significantly negatively associated with firm profitability $(R O A)$ for the whole sample and for both the Big Five and non-Big Five client samples. However, the other audit risk variables, $C A C L$ and $L E V$, cannot significantly explain audit opinions, with the exception that $L E V$ is positively associated with modified opinions in the non-Big Five regression. This is consistent with the auditing fee results that among the audit risk variable, only $R O A$ is significantly negatively associated with auditing fees. The asset composition and organization complexity variables seem to give surprising results. The coefficients of GROUP and $A R$ are negative and statistically significant in all three regressions, differing from prior predictions. Membership in a corporate group may reduce the propensity for getting modified opinions if group firms manage to reduce bankruptcy risk using related-party transactions as cross-subsidies. Also, $R O A$ is positively correlated with $A R$, which may have induced multicollinearity between the two variables. Consistent with this 
conjecture, when the regression is separately estimated using high and low profitability samples, a procedure used in the auditor choice and auditing fee regressions, the coefficient of $A R$ becomes statistically insignificant in both samples. Finally, the coefficient of $D C V^{*} R O A$ is negative and statistically significant for the whole sample and the Big Five sample regressions, but not for the non-Big Five sample regression.

The whole sample and the Big Five sample results are consistent with $H 3$ that low earnings would more easily trigger a modified opinion for auditees with divergence of control and ownership. When taking the auditing fee and opinion results together, we find that Big Five auditors take into consideration their auditee's ownership structure in setting auditing prices and issuing modified opinions, while non-Big Five auditors do not.

Since Table 2 shows that modified opinions are not evenly distributed across the economies, we perform two diagnostic analyses. We repeat the regressions in Table 10 by dropping Indonesia, which had no modified opinion from 1994 to 1996, and the results remain qualitatively the same. In addition, Table 2 shows that in 1995 and 1996, there were considerably more modified opinions in Thailand with $15(19.7 \%)$ in 1995 and $11(13.4 \%)$ in 1996 . The regression results in Table 10 also remain unchanged when both Indonesia and Thailand are dropped from the sample.

In summary, the results from the auditing opinion regressions indicate that Big Five auditors in East Asia are more stringent with clients with agency problems. This evidence corroborates earlier fee premium results that Big Five auditors fulfill the monitoring role by exerting more auditing efforts on firms subject to agency conflicts.

\section{Conclusion}


The concentrated ownership of East Asian corporations gives rise to conflicts of interest between controlling owners and minority shareholders. One big concern about containing the controlling owners' self-interested activities is that conventional internal and external governance mechanisms such as boards of directors and takeover markets are typically weak when corporate ownership is concentrated as in East Asia. To mitigate this agency problem, theory suggests that the controlling owners may find ways to employ bonding mechanisms to assure the minority shareholders that their interests would be protected. We examine if external independent auditors play this role in East Asia.

We find that in East Asia, firms subject to large agency conflicts, indicated by their high control concentration and a large separation of control and ownership, are more likely to hire Big Five auditors than firms less subject to agency problem. We further find that the auditee's ownership structure is associated with its choice of auditor only among small and high-risk auditees, whose threat of expropriation by ultimate owners is high, but not among large and low risk auditors whose threat of expropriation is low. Our results also show that Big Five auditors take into consideration their auditees' ownership structure when making pricing and opinion decisions, while non-Big Five auditors do not. More specifically, Big Five auditors charge clients with controlling owners who enjoy effective control but actually own a small stake in the firm a premium. Lastly, we document that poor earnings can more likely trigger a modified opinion about Big Five clients with large agency problems, which suggests that Big Five auditors lower the modification threshold as their clients' agency problems increase. The overall evidence lends support to the agency theory and suggests that auditors play a crucial monitoring role to mitigate agency problems in emerging markets. 
This paper contributes to the corporate governance literature by linking the corporate ownership structure with mandatory external audits in the context of emerging markets. It provides evidence of how agency conflicts between majority and minority shareholders affect the choice of auditors, and the auditing fees and auditing opinions of the auditor. Auditor types, fees and opinions provide quantifiable measures of the quality of this corporate governance mechanism. From the policy perspective, this study sheds light on the question of whether voluntary governance mechanisms were at work prior to the Asian Financial Crisis.

Future research could examine other corporate governance mechanisms in emerging markets. Potential candidates could include institutional owners, financial analysts, and prominent directors. Such research will not only complement existing research that mostly focuses on developed economies but also provide policy suggestions to firms and governments in emerging markets that are striving to reform their corporate governance. 


\section{References:}

Asian Corporate Governance Association, 2000. Building Stronger Boards and Companies in Asia. Hong Kong: Asian Corporate Governance Association.

Asian Wall Street Journal, 2001, “Taekwang Gets a Taste of Shareholder Activism.” (June 13).

Backman, Michael, 1999, Asian Eclipse: Exposing the Dark Side of Business in Asia, Singapore: John Wiley \& Sons (Asia).

Becker, Connie L., Mark L. DeFond, Jim Jiambalvo, K. R. Subramanyam, 1998, "The Effect of Audit Quality on Earnings Management," Contemporary Accounting Research 15, 1-24.

Bradley, M., and E. H. Kim, 1985, The Tender Offer as A Takeover Device: Its Evolution, the Free Rider Problem and the Prisoner's Dilemma, Unpublished working paper (University of Michigan).

Carcello, Joseph, Dana R. Hermanson, Terry L. Neal and Richard R. Riley, Jr., 2000, "Board Characteristics and Audit Fees," Working Paper, University of Tennessee.

Chow, Chee, 1982, “The Demand for External Auditing: Size, Debt and Ownership Influence." The Accounting Review 57, 272-291.

Clarkson, Peter, and Daniel Simunic, 1994, "The Association between Audit Quality, Retained Ownership, and Firm-specific Risk in U.S. vs. Canadian IPO Markets." Journal of Accounting and Economics 17: 207-228.

Claessens, Stijn, Simeon Djankov, Joseph P.H. Fan, and Larry H.P. Lang, forthcoming, "Disentangling the Incentive and Entrenchment Effects of Large Shareholdings," Journal of Finance.

Claessens, Stijn, Simeon Djankov, Joseph P.H. Fan, and Larry H.P. Lang, 2000, “The Costs of Group Affiliation: Evidence from East Asia,” Working Paper, World Bank.

Claessens, S., S. Djankov, and L.H.P. Lang, 2000, The Separation of Ownership and Control in East Asian Corporations, Journal of Financial Economics 58, 81-112.

The Committee on Corporate Governance, 1999. Code of Best Practice for Corporate Governance. Korea: The Committee on Corporate Governance.

Craswell, Alan, Jere Francis, and Stephen Taylor, 1995, "Auditor Brand Name Reputations and Industry Specialization.” Journal of Accounting and Economics 20, 297-322.

DeFond, Mark, 1992, "The Association between Changes in Client Firm Agency Costs and Auditor Switching." Auditing: A Journal of Practice and Theory 11, 16-31. 
DeFond, Mark, and James Jiambalvo, 1993, "Factors Related to Auditor-Client Disagreements Over Income-Increasing Accounting Methods. Contemporary Accounting Research 9, 1431.

DeFond, Mark, Jere Francis and T.J. Wong, 2000, "Auditor Industry Specialization and Market Segmentation: Evidence from Hong Kong." Auditing: A Journal of Practice and Theory $19,49-66$.

DeFond, Mark, T.J. Wong, and Shuhua Li, 2000, "The Impact of Improved Auditor Independence on Audit Market Concentration in China." Journal of Accounting and Economics 28, 269-305.

Eichenseher, John W. and David Shields, 1989, "Corporate Capital Structure and Auditor 'Fit'." Advances in Accounting (Supplement 1):39-56.

Fan, Joseph P.H., and T.J. Wong, 2000, "Corporate Ownership Structure and the Informativeness of Accounting Earnings in East Asia," Working Paper, Hong Kong University of Science \& Technology.

Francis, Jere, 1984, "The Effect of Audit Firm Size and Audit Prices," Journal of Accounting and Economics, 6, 133-152.

Francis, Jere, and Earl Wilson, 1988, “Auditor Changes: a Joint Test of Theories Relating to Agency Costs and Auditor Differentiation." The Accounting Review 63, 663-682.

Deli, Daniel N., and Stuart L. Gillan, 2000, "On the Demand for Independent and Active Audit Committees," Journal of Corporate Finance, 6, 427-445.

Gul, Ferdinand A., Judy Tsui, and Charles J. P. Chen, 1998, “Agency Costs and Audit Pricing: Evidence on Discretionary Accruals," Working Paper, City University of Hong Kong.

Healy, Paul, 1986?

The Hong Kong Economic Journal. "Monitoring Auditors.” (April 22, 1999).

Jensen, Michael, and William Meckling, 1976, "Theory of the Firm: Managerial Behavior, Agency Costs and Ownership Structure," Journal of Financial Economics 3, 305-360.

Johnson, S., P. Boone, A. Breach, and E. Friedman, 2000, Corporate Governance in the Asian Financial Crisis, Journal of Financial Economics 58, 141-186.

Klein, April, 2000a, "Causes and Consequences of Variations in Audit Committee Composition," Working Paper, New York University.

Klein, April, 2000b, "Audit Committee, Board of Director Characteristics, and Earnings Management," Working Paper, New York University. 
La Porta, Rafael, Florencio Lopez-De-Silanes, and Andrei Shleifer, 1999, "Corporate Ownership Around the World," Journal of Finance, 54, 471-518.

La Porta, Rafael, Florencio Lopez-de-Silanes, Andrei Shleifer, and Robert W. Vishny, 2000, "Investor Protection and Corporate Valuation," Working Paper, Harvard University.

Lemmon, Michael L., and Karl V. Lins, 2001, “Ownership Structure, Corporate Governance, And Firm Value: Evidence from the East Asian Financial Crisis," Working Paper, University of Utah.

Mitton, Todd, 2000, "A Cross-firm Analysis of the Impact of Corporate Governance on the East Asian Financial Crisis, Working Paper, Brigham Young University.

New Straits Times Press, Feb. 16, 1997

Palmrose, Zoe-Vonna,1984, "The Demand for Quality-Differentiated Audit Services in an Agency-cost Setting: An Empirical Investigation. Proceedings of the 1984 University of Illinois Auditing Research Symposium. Urbana, IL: University of Illionois at UrbanaChampaign.

Peasnell, K.V., P.F. Pope and S. Young, 2000, "Board Monitoring and Earnings Management: Do Outside Directors Influence Abnormal Accruals?" Working Paper, Lancaster University.

PricewaterhouseCoopers, 1999. Corporate Governance 1999 Survey of Institutional Investors. Singapore: PricewaterhouseCoopers LLP.

Rahman, M. Zubaidur, 1999, "The Role of Accounting Disclosure in the East Asian Financial Crisis: Lessons Learned?" United Nations Conference on Trade and Development, Division of Investments, Technology and Enterprise Development, Enterprise Development Strategies, Finance and Accounting Section, E. 9080 Palais des Nations, 1211 Geneva, Switzerland, March 1999.

Securities Exchange Commission of Thailand, 1999, Research Paper on Enhancing Good Corporate Governance of Thai Listed Companies (July).

Schipper, Katherine, 2000, "Financial Accounting and Reporting Research in Transition Economies," Working Paper, Duke University.

Shleifer, A. and R. Vishny, 1997, A Survey of Corporate Governance, Journal of Finance 52, 737-783.

Simon, D., R. Ramanan, and A. Dugar, 1986, "The Market for Audit Services in India: An Empirical Examination," International Journal of Accounting (Spring): 285-295. 
Simon, Daniel, Susan Teo, and Gregory Trompeter, 1992, "A Comparative Study of the Market for Services in Hong Kong, Malaysia and Singapore." The International Jorunal of Acconting 27, 234-240.

Simunic, Daniel, 1980. "The Pricing of Audit Services: Theory and Evidence." Journal of Accounting Research 18, 161-190.

Simunic, Daniel and Michael Stein, 1987, "Product Differentiation in Auditing: Auditor Choice in the Market for Unseasoned New Issues." Research Monograph Number 13. Vancouver: The Canadian Certified General Accountants' Research Foundation.

, and _ 1996, "The Impact of Litigation Risk on Audit Pricing: A Review of the Economics and the Evidence." Auditing: A Journal of Practice and Theory Supplement 15: 119-134.

Singh, Rajeshpal, 1997, "When We Do It Our Way," New Straits Times Press, (February 16).

Teoh, Siew Hong and T.J. Wong, 1993, "Perceived Auditor Quality and the Earnings Response Coefficient." The Accounting Review 68, 346-367.

Titman, Sheridan, and Brett Trueman, 1986, "Information Quality and the Valuation of New Issues," Journal of Accounting and Economics 8, 159-172.

U.S. Securities and Exchange Commision, 1999, Final Rule on Audit Committee Disclosure.

Watts, Ross and Jerald Zimmerman, 1983, "Agency Problems, Auditing, and the Theory of the Firm: Some Evidence.” Journal of Law and Economics, 613-633. 
Table 1

Percentage of Firms That Hire Big Five or Big Five-Affiliated Auditors by Economy And by Year

\begin{tabular}{lcccc}
\hline Economy & $1994-1996$ & 1994 & 1995 & 1996 \\
\hline Hong Kong & $80.6(525)$ & $80.0(100)$ & $78.5(208)$ & $83.1(217)$ \\
Indonesia & $87.7(271)$ & $84.2(64)$ & $86.3(88)$ & $90.8(119)$ \\
Korea (South) & $71.4(422)$ & $72.0(136)$ & $72.1(119)$ & $70.5(167)$ \\
Malaysia & $74.0(304)$ & $79.4(73)$ & $71.7(104)$ & $73.0(127)$ \\
Philippines & $62.3(127)$ & $19.2(9)$ & $61.8(47)$ & $87.7(71)$ \\
Singapore & $88.3(362)$ & $85.5(71)$ & $88.8(142)$ & $89.2(149)$ \\
Taiwan & $56.1(125)$ & $54.8(34)$ & $54.4(43)$ & $58.5(48)$ \\
Thailand & $65.3(209)$ & $59.3(51)$ & $65.5(76)$ & $69.5(82)$ \\
& & & & \\
All Economies & $75.2(3119)$ & $70.2(538)$ & $74.6(827)$ & $78.3(980)$
\end{tabular}

$\overline{\text { Numbers in brackets are total client numbers of Big Five or Big Five- }}$ affiliated auditors. 
Table 2

Percentage of Modified Opinions by Economy and by Year

\begin{tabular}{lcccc}
\hline Economy & $1994-1996$ & 1994 & 1995 & 1996 \\
\hline Hong Kong & $1.80(8)$ & $0.00(0)$ & $1.08(2)$ & $3.33(6)$ \\
Indonesia & $0.00(0)$ & $0.00(0)$ & $0.00(0)$ & $0.00(0)$ \\
Korea (South) & $0.20(1)$ & $0.68(1)$ & $0.00(0)$ & $0.00(0)$ \\
Malaysia & $0.65(2)$ & $1.41(1)$ & $0.95(1)$ & $0.00(0)$ \\
Philippines & $4.88(6)$ & $7.14(2)$ & $4.17(2)$ & $4.26(2)$ \\
Singapore & $0.92(3)$ & $0.00(0)$ & $0.79(1)$ & $1.48(2)$ \\
Taiwan & $0.49(1)$ & $0.00(0)$ & $0.00(0)$ & $1.30(1)$ \\
Thailand & $13.33(28)$ & $3.85(2)$ & $19.74(15)$ & $13.41(11)$ \\
& & & & \\
All Economies & $2.10(49)$ & $1.08(6)$ & $2.50(21)$ & $2.35(22)$ \\
& & & & \\
\hline Absolute
\end{tabular}

Absolute numbers of modified opinions are in brackets. 
Table 3

Audit Fees by Economy And by Year

\begin{tabular}{|c|c|c|c|c|c|c|c|c|}
\hline \multirow[t]{2}{*}{ Economy } & \multicolumn{2}{|c|}{$1994-1996$} & \multicolumn{2}{|c|}{1994} & \multicolumn{2}{|c|}{1995} & \multicolumn{2}{|c|}{1996} \\
\hline & Mean & Median & Mean & Median & Mean & Median & Mean & Median \\
\hline \multicolumn{9}{|c|}{ Panel A : Fees in US Dollars (thousands) } \\
\hline Hong Kong & 350.38 & 200.67 & 342.41 & 202.39 & 337.53 & 195.78 & 368.79 & 208.03 \\
\hline Malaysia & 130.30 & 50.38 & 112.32 & 50.85 & 111.28 & 49.20 & 161.02 & 51.09 \\
\hline Singapore & 206.71 & 132.90 & 196.63 & 119.34 & 193.77 & 124.82 & 227.65 & 145.41 \\
\hline $\begin{array}{l}\text { All Three } \\
\text { Economies }\end{array}$ & 243.92 & 138.12 & 227.66 & 131.67 & 232.62 & 135.76 & 266.71 & 146.68 \\
\hline \multicolumn{9}{|c|}{ Panel B : Percentage of Fees over Total Assets } \\
\hline Hong Kong & 0.11 & 0.09 & 0.09 & 0.08 & 0.11 & 0.09 & 0.11 & 0.09 \\
\hline Malaysia & 0.04 & 0.02 & 0.03 & 0.02 & 0.03 & 0.02 & 0.05 & 0.02 \\
\hline Singapore & 0.11 & 0.07 & 0.10 & 0.06 & 0.11 & 0.07 & 0.12 & 0.07 \\
\hline $\begin{array}{l}\text { All Three } \\
\text { Economies }\end{array}$ & 0.09 & 0.05 & 0.08 & 0.05 & 0.09 & 0.06 & 0.09 & 0.06 \\
\hline
\end{tabular}


Table 4

Comparison of Firm Characteristics between Big Five Clients And Non-Big Five Clients (1996)

\begin{tabular}{|c|c|c|c|c|c|c|c|c|}
\hline & All firms & $\begin{array}{l}\text { Firms } \\
\text { hiring big- } \\
\text { five } \\
\text { auditors }\end{array}$ & $\begin{array}{c}\text { Firms } \\
\text { hiring local } \\
\text { auditors }\end{array}$ & $\begin{array}{c}\text { T-statistics } \\
\text { for } \\
\text { difference }\end{array}$ & All firms & $\begin{array}{l}\text { Firms } \\
\text { hiring big- } \\
\text { five } \\
\text { auditors }\end{array}$ & $\begin{array}{c}\text { Firms } \\
\text { hiring local } \\
\text { auditors }\end{array}$ & $\begin{array}{l}\text { Z-statistics } \\
\text { for } \\
\text { difference }\end{array}$ \\
\hline$S I Z E$ & 2,079 & 2,224 & 1,552 & $1.94 *$ & 386 & 388 & 363 & 0.75 \\
\hline$L E V$ & 0.14 & 0.14 & 0.14 & -0.10 & 0.11 & 0.10 & 0.12 & $-1.35^{*}$ \\
\hline$E V(\%)$ & 0.82 & 1.12 & -0.28 & $1.80 *$ & 0.00 & 0.00 & 0.00 & $1.44 *$ \\
\hline$C V$ & 0.87 & 0.86 & 0.89 & $-2.38 * * *$ & 1.00 & 1.00 & 1.00 & $-2.27 * *$ \\
\hline GROUP & 0.59 & 0.61 & 0.54 & $2.05^{* *}$ & 1.00 & 1.00 & 1.00 & $2.07 * *$ \\
\hline PYRAMID & 0.37 & 0.38 & 0.35 & 0.87 & 0.00 & 0.00 & 0.00 & 0.86 \\
\hline
\end{tabular}

$\overline{S I Z E}$ is total assets are in millions of U.S. dollars; $L E V$ is long-term debt divided by total assets; $E V$ is the percentage of voting rights possessed by the largest ultimate owner of the firm minus the median percentage of voting rights in the corresponding economy; $C V$ is the ratio of cash flow rights to voting rights of the largest ultimate owner; $G R O U P=1$ when the client firm is a member of a corporate group, and 0 otherwise; PYRAMID $=1$ when the client firm is controlled by an affiliated firm through a stock pyramid, and 0 otherwise. ***, ***, denote statistical significance at $1 \%, 5 \%$, and $10 \%$ in two-tailed test. 
Table 5

\section{Logit Regression Results for Auditor Choice}

\begin{tabular}{|c|c|c|c|c|}
\hline & 1994-1996 & 1994 & 1995 & 1996 \\
\hline Intercept & $\begin{array}{c}-0.11 \\
(-0.21)\end{array}$ & $\begin{array}{c}-0.12 \\
(-0.12)\end{array}$ & $\begin{array}{c}0.02 \\
(0.03)\end{array}$ & $\begin{array}{c}0.58 \\
(0.65)\end{array}$ \\
\hline SIZE & $\begin{array}{c}0.10^{* * * *} \\
(3.44)\end{array}$ & $\begin{array}{c}0.06 \\
(0.98)\end{array}$ & $\begin{array}{c}0.07 \\
(1.53)\end{array}$ & $\begin{array}{c}0.14 * * * \\
(2.86)\end{array}$ \\
\hline LEV & $\begin{array}{l}-0.05 \\
(-0.18)\end{array}$ & $\begin{array}{l}-0.06 \\
(-0.11)\end{array}$ & $\begin{array}{c}-0.18 \\
(-0.34)\end{array}$ & $\begin{array}{c}0.02 \\
(0.03)\end{array}$ \\
\hline GROUP & $\begin{array}{c}0.07 \\
(0.68)\end{array}$ & $\begin{array}{c}-0.02 \\
(-0.12)\end{array}$ & $\begin{array}{c}0.07 \\
(0.42)\end{array}$ & $\begin{array}{c}0.08 \\
(0.45)\end{array}$ \\
\hline PYRAMID & $\begin{array}{l}-0.24 * \\
(-1.81)\end{array}$ & $\begin{array}{c}-0.11 \\
(-0.40)\end{array}$ & $\begin{array}{c}-0.13 \\
(-0.58)\end{array}$ & $\begin{array}{c}-0.48^{* *} \\
(-2.10)\end{array}$ \\
\hline DEV & $\begin{array}{c}1.18^{* * * *} \\
(2.77)\end{array}$ & $\begin{array}{l}1.39^{*} \\
(1.67)\end{array}$ & $\begin{array}{l}1.40 * * \\
(2.00)\end{array}$ & $\begin{array}{c}0.71 \\
(0.96)\end{array}$ \\
\hline $\mathrm{CV}$ & $\begin{array}{c}-0.12 \\
(-0.37)\end{array}$ & $\begin{array}{c}0.44 \\
(0.70)\end{array}$ & $\begin{array}{c}0.23 \\
(0.41)\end{array}$ & $\begin{array}{l}-1.01 * \\
(-1.70)\end{array}$ \\
\hline $\mathrm{DEV} * \mathrm{CV}$ & $\begin{array}{c}-1.26 * * * \\
(-2.67)\end{array}$ & $\begin{array}{l}-1.73^{*} \\
(-1.85)\end{array}$ & $\begin{array}{l}-1.47 * \\
(-1.91)\end{array}$ & $\begin{array}{c}-0.68 \\
(-0.84)\end{array}$ \\
\hline Pseudo R2 & 0.06 & 0.12 & 0.06 & 0.07 \\
\hline Observations & 3119 & 760 & 1108 & 1251 \\
\hline Chi-square & 214.78 & 108.77 & 69.92 & 92.58 \\
\hline Degree of Freedom & 22 & 20 & 20 & 20 \\
\hline P-value & 0.0001 & 0.0001 & 0.0001 & 0.0001 \\
\hline
\end{tabular}

$\overline{A U D I T O R}=1$ when auditor is a Big Five accounting firm, and 0 otherwise; $S I Z E_{i t}$ = natural logarithm of total assets in millions of U.S. dollars at year $\mathrm{t} ; L E V_{i t}=$ long-term debt divided by total assets at year $\mathrm{t}$; $\operatorname{GROUP}_{i}=1$ when the client firm is a member of a corporate group, and 0 otherwise; $P Y R A M I D_{i}=1$ when the client firm is controlled by an affiliated firm through a stock pyramid, and 0 otherwise; $D E V_{i}=1$ when the percentage of voting rights possessed by the largest ultimate owner of the firm exceeds the median in the corresponding economy, and 0 otherwise; $C V_{i}=$ the ratio of cash flow rights to voting rights of the largest ultimate owner; Fixed effects $=$ dummy variables controlling for fixed effects of industries, calendar years and economies. For simplicity, results for the fixed effects are not reported. ***, $* *$, and $*$ denote $1 \%, 5 \%$ and $10 \%$-tailed test. 
William Davidson Institute Working Paper 400

Table 6

Logit Regression Results of Auditor Choice by Profitability, Leverage, and Firm Size Partitions

AUDITOR $_{i t}=a_{0}+a_{1} \log \left(\right.$ SIZE $\left._{i t}\right)+a_{2} L E V_{i t}+a_{3}$ GROUP $_{i}+a_{4}$ PYRAMID $_{i}+a_{5} D E V_{i}+a_{6} C V_{i}+a_{7}$ DEV $_{i} * C V_{i}+a_{8}$ fixed effects $+u_{i t}$

\begin{tabular}{|c|c|c|c|c|c|c|}
\hline & Low profit firms & High profit firms & High leverage firms & Low leverage firms & Small firms & Large firms \\
\hline Intercept & $\begin{array}{c}1.20 \\
(1.57)\end{array}$ & $\begin{array}{c}-1.23 \\
(-1.50)\end{array}$ & $\begin{array}{c}-0.38 \\
(-0.41)\end{array}$ & $\begin{array}{c}-2.25 * * \\
(-2.17)\end{array}$ & $\begin{array}{c}-0.57 \\
(-0.55)\end{array}$ & $\begin{array}{c}0.64 \\
(0.62)\end{array}$ \\
\hline Log(ASSETS) & $\begin{array}{c}0.05 \\
(1.27)\end{array}$ & $\begin{array}{c}0.17 * * * \\
(3.30)\end{array}$ & $\begin{array}{c}0.06 \\
(1.04)\end{array}$ & $\begin{array}{c}0.37 * * * \\
(5.62)\end{array}$ & $\begin{array}{l}0.15^{*} \\
(1.87)\end{array}$ & $\begin{array}{c}0.09 \\
(1.54)\end{array}$ \\
\hline LEV & $\begin{array}{c}-0.33 \\
(-0.81)\end{array}$ & $\begin{array}{c}0.27 \\
(0.65)\end{array}$ & $\begin{array}{c}0.13 \\
(0.33)\end{array}$ & $\begin{array}{c}-3.03 * * * \\
(-3.24)\end{array}$ & $\begin{array}{c}0.30 \\
(0.79)\end{array}$ & $\begin{array}{c}-0.55 \\
(-1.11)\end{array}$ \\
\hline GROUP & $\begin{array}{c}0.13 \\
(0.91)\end{array}$ & $\begin{array}{c}-0.06 \\
(-0.40)\end{array}$ & $\begin{array}{l}0.28 * \\
(1.66)\end{array}$ & $\begin{array}{c}-0.26 \\
(-1.49)\end{array}$ & $\begin{array}{c}-0.01 \\
(-0.06)\end{array}$ & $\begin{array}{c}0.07 \\
(0.50)\end{array}$ \\
\hline PYRAMID & $\begin{array}{c}-0.52 * * * \\
(-2.80)\end{array}$ & $\begin{array}{c}0.02 \\
(0.09)\end{array}$ & $\begin{array}{c}-0.27 \\
(-1.29)\end{array}$ & $\begin{array}{c}0.18 \\
(0.78)\end{array}$ & $\begin{array}{c}-0.15 \\
(-0.80)\end{array}$ & $\begin{array}{c}-0.43^{* *} \\
(-2.24)\end{array}$ \\
\hline DEV & $\begin{array}{l}1.19 * * \\
(1.99)\end{array}$ & $\begin{array}{l}1.48^{* *} \\
(2.31)\end{array}$ & $\begin{array}{c}1.79 * * * \\
(2.54)\end{array}$ & $\begin{array}{c}0.47 \\
(0.66)\end{array}$ & $\begin{array}{c}1.54 * * * \\
(2.51)\end{array}$ & $\begin{array}{c}1.00 \\
(1.62)\end{array}$ \\
\hline $\mathrm{CV}$ & $\begin{array}{c}-0.13 \\
(-0.30)\end{array}$ & $\begin{array}{c}-0.06 \\
(-0.11)\end{array}$ & $\begin{array}{c}0.34 \\
(0.67)\end{array}$ & $\begin{array}{c}-0.36 \\
(-0.62)\end{array}$ & $\begin{array}{c}-0.30 \\
(-0.64)\end{array}$ & $\begin{array}{c}0.02 \\
(0.05)\end{array}$ \\
\hline $\mathrm{DEV} * \mathrm{CV}$ & $\begin{array}{c}-1.69 * * * \\
(-2.53)\end{array}$ & $\begin{array}{l}-1.23^{*} \\
(-1.74)\end{array}$ & $\begin{array}{c}-1.99 * * * \\
(-2.54)\end{array}$ & $\begin{array}{c}-0.15 \\
(-0.19)\end{array}$ & $\begin{array}{c}-1.63 * * * \\
(-2.38)\end{array}$ & $\begin{array}{c}-1.05 \\
(-1.53)\end{array}$ \\
\hline Pseudo R2 & 0.07 & 0.09 & 0.09 & 0.10 & 0.07 & 0.10 \\
\hline Observations & $\begin{array}{c}1574 \\
12251\end{array}$ & $\begin{array}{c}1545 \\
15591\end{array}$ & $\begin{array}{c}1166 \\
11750\end{array}$ & $\begin{array}{c}1172 \\
13203\end{array}$ & $\begin{array}{c}1530 \\
11419\end{array}$ & $\begin{array}{c}1589 \\
17419\end{array}$ \\
\hline $\begin{array}{l}\text { Chi-square } \\
\text { Degree of Freedom }\end{array}$ & $\begin{array}{c}122.51 \\
22\end{array}$ & $\begin{array}{c}155.91 \\
22\end{array}$ & $\begin{array}{c}117.50 \\
22\end{array}$ & $\begin{array}{c}132.03 \\
22\end{array}$ & $\begin{array}{c}114.19 \\
22\end{array}$ & $\begin{array}{c}174.19 \\
22\end{array}$ \\
\hline P-value & 0.0001 & 0.0001 & 0.0001 & 0.0001 & 0.0001 & 0.0001 \\
\hline
\end{tabular}




\section{William Davidson Institute Working Paper 400}

$A U D I T O R=1$ when auditor is a Big Five accounting firm, and 0 otherwise; $S I Z E_{i t}=$ natural logarithm of total assets in millions of U.S. dollars at year $\mathrm{t} ; L E V_{i t}=$ long-term debt divided by total assets at year t; GROUP $P_{i}=1$ when the client firm is a member of a corporate group, and 0 otherwise; $P Y R A M I D_{i}=1$ when the client firm is controlled by an affiliated firm through a stock pyramid, and 0 otherwise; $D E V_{i}=1$ when the percentage of voting rights possessed by the largest ultimate owner of the firm exceeds the median in the corresponding economy, and 0 otherwise; $C V_{i}=$ the ratio of cash flow rights to voting rights of the largest ultimate owner; Fixed effects = dummy variables controlling for fixed effects of industries, calendar years and economies. For simplicity, results for the fixed effects are not reported. The sample is classified into high (low) subgroup when the partitioning variable of that year is higher than its corresponding three-year median of the economy. The partitioning variable for profitability is net income over total assets, for leverage is total liabilities over total assets and firm size is total assets. ${ }^{* *}, * *$, and $*$ denote $1 \%, 5 \%$ and $10 \% 2$-tailed test. 
William Davidson Institute Working Paper 400

Table 7

Logit Regression Results of Auditor Choice by Economy

$A U D I T O R_{i t}=a_{0}+a_{1} \log \left(S I Z E_{i t}\right)+a_{2} L E V_{i t}+a_{3} G R O U P_{i}+a_{4} P Y R A M I D_{i}+a_{5} D E V_{i}+a_{6} C V_{i}+a_{7} D E V_{i} * C V_{i}+a_{8}$ fixed effects $+u_{i t}$

\begin{tabular}{|c|c|c|c|c|c|c|c|c|}
\hline & Hong Kong & Indonesia & Korea (South) & Malaysia & The Philippines & Singapore & Taiwan & Thailand \\
\hline Intercept & $\begin{array}{c}3.57 * * * \\
(2.35)\end{array}$ & $\begin{array}{c}-0.71 \\
(-0.34)\end{array}$ & $\begin{array}{c}-5.22 * * * \\
(-2.90)\end{array}$ & $\begin{array}{c}3.54 * * * \\
(2.42)\end{array}$ & $\begin{array}{c}-1.91 \\
(-0.78)\end{array}$ & $\begin{array}{c}-7.14 * * * \\
(-3.33)\end{array}$ & $\begin{array}{c}-0.71 \\
(-0.35)\end{array}$ & $\begin{array}{c}-1.37 \\
(-0.82)\end{array}$ \\
\hline Log(ASSETS) & $\begin{array}{l}-0.14 * * \\
(-1.96)\end{array}$ & $\begin{array}{c}0.31 * * \\
(2.10)\end{array}$ & $\begin{array}{c}0.48 * * * \\
(5.61)\end{array}$ & $\begin{array}{c}-0.08 \\
(-1.08)\end{array}$ & $\begin{array}{l}-0.29 * * \\
(-1.97)\end{array}$ & $\begin{array}{c}0.67 * * * \\
(4.51)\end{array}$ & $\begin{array}{c}0.11 \\
(1.02)\end{array}$ & $\begin{array}{c}-0.04 \\
(-0.45)\end{array}$ \\
\hline LEV & $\begin{array}{c}-0.15 \\
(-0.15)\end{array}$ & $\begin{array}{c}0.46 \\
(0.34)\end{array}$ & $\begin{array}{c}0.68 \\
(1.37)\end{array}$ & $\begin{array}{c}0.69 \\
(0.73)\end{array}$ & $\begin{array}{c}1.13 \\
(0.62)\end{array}$ & $\begin{array}{c}-3.68 * * * \\
(-2.75)\end{array}$ & $\begin{array}{c}-0.13 \\
(-0.08)\end{array}$ & $\begin{array}{c}-0.52 \\
(-0.65)\end{array}$ \\
\hline GROUP & $\begin{array}{c}-0.61 * * * \\
(-2.52)\end{array}$ & $\begin{array}{c}-0.00 \\
(-0.01)\end{array}$ & $\begin{array}{c}-0.15 \\
(-0.63)\end{array}$ & $\begin{array}{c}0.57 * * \\
(1.97)\end{array}$ & $\begin{array}{l}1.01 * * \\
(2.10)\end{array}$ & $\begin{array}{c}0.79 \\
(1.57)\end{array}$ & $\begin{array}{c}0.16 \\
(0.52)\end{array}$ & $\begin{array}{c}-0.14 \\
(-0.51)\end{array}$ \\
\hline PYRAMID & $\begin{array}{c}-1.06 * * \\
(-1.98)\end{array}$ & $\begin{array}{c}0.52 \\
(0.92)\end{array}$ & $\begin{array}{c}-0.48 \\
(-1.61)\end{array}$ & $\begin{array}{c}-0.74 * * \\
(-2.08)\end{array}$ & $\begin{array}{l}-0.88 * \\
(-1.88)\end{array}$ & $\begin{array}{c}-0.82 \\
(-1.49)\end{array}$ & $\begin{array}{c}0.13 \\
(0.25)\end{array}$ & $\begin{array}{c}-0.38 \\
(-0.80)\end{array}$ \\
\hline DEV & $\begin{array}{c}2.86^{* * *} * \\
(3.11)\end{array}$ & $\begin{array}{c}-1.78 \\
(-1.24)\end{array}$ & $\begin{array}{c}-1.01 \\
(-0.90)\end{array}$ & $\begin{array}{c}7.77 * * * \\
(2.77)\end{array}$ & $\begin{array}{c}10.24 * * \\
(2.12)\end{array}$ & $\begin{array}{c}1.17 \\
(0.70)\end{array}$ & $\begin{array}{c}-4.09 \\
(-1.60)\end{array}$ & $\begin{array}{c}0.73 \\
(0.39)\end{array}$ \\
\hline $\mathrm{CV}$ & $\begin{array}{c}-0.54 \\
(-0.46)\end{array}$ & $\begin{array}{c}-1.45 \\
(-1.03)\end{array}$ & $\begin{array}{c}-3.65 * * * \\
(-3.74)\end{array}$ & $\begin{array}{c}0.32 \\
(0.36)\end{array}$ & $\begin{array}{c}2.50 * * \\
(2.00)\end{array}$ & $\begin{array}{c}2.40 * * * \\
(2.39)\end{array}$ & $\begin{array}{c}-0.77 \\
(-0.63)\end{array}$ & $\begin{array}{c}0.95 \\
(0.73)\end{array}$ \\
\hline $\mathrm{DEV} * \mathrm{CV}$ & $\begin{array}{c}-3.34 * * * \\
(-3.27)\end{array}$ & $\begin{array}{c}2.15 \\
(1.28)\end{array}$ & $\begin{array}{c}1.52 \\
(1.20)\end{array}$ & $\begin{array}{c}-8.04 * * * \\
(-2.75)\end{array}$ & $\begin{array}{l}-9.78 * * \\
(-1.96)\end{array}$ & $\begin{array}{c}-2.36 \\
(-1.18)\end{array}$ & $\begin{array}{c}3.73 \\
(1.34)\end{array}$ & $\begin{array}{c}-1.03 \\
(-0.53)\end{array}$ \\
\hline Pseudo R2 & 0.08 & 0.08 & 0.13 & 0.09 & 0.32 & 0.10 & 0.12 & 0.08 \\
\hline Observations & 651 & 309 & 591 & 411 & 204 & 410 & 223 & 320 \\
\hline Chi-square & 54.63 & 27.13 & 90.97 & 39.07 & 96.78 & 44.45 & 29.96 & 26.25 \\
\hline Degree of Freedom & 15 & 15 & 15 & 15 & 15 & 15 & 15 & 15 \\
\hline P-value & 0.0001 & 0.0001 & 0.0001 & 0.0001 & 0.0001 & 0.0001 & 0.0001 & 0.0001 \\
\hline
\end{tabular}




\section{William Davidson Institute Working Paper 400}

$A U D I T O R=1$ when auditor is a Big Five accounting firm, and 0 otherwise; $S I Z E_{i t}=$ natural logarithm of total assets in millions of U.S. dollars at year $\mathrm{t} ; L E V_{i t}$ $=$ long-term debt divided by total assets at year $t ; G R O U P_{i}=1$ when the client firm is a member of a corporate group, and 0 otherwise; $P Y R A M I D_{i}=1$ when the client firm is controlled by an affiliated firm through a stock pyramid, and 0 otherwise; $D E V_{i}=1$ when the percentage of voting rights possessed by the largest ultimate owner of the firm exceeds the median in the corresponding economy, and 0 otherwise; $C V_{i}=$ the ratio of cash flow rights to voting rights of the largest ultimate owner; Fixed effects = dummy variables controlling for fixed effects of industries, calendar years and economies. For simplicity, results for the fixed effects are not reported. $* * * * *$, and $*$ denote $1 \%, 5 \%$ and $10 \%$ 2-tailed test. 


\section{Table 8}

\section{Ordinary Least Squares Regression Results of Audit Fee}

$$
\begin{aligned}
L A F_{i t}= & b_{0}+b_{1} \log \left(S I Z E_{i t}\right)+b_{2} R O A_{i t}+b_{3} L E V_{i t}+b_{4} C A C L_{i t}+b_{5} A R_{i t}+b_{6} I N V_{i t} \\
& +b_{7} \text { GROUP }+b_{8} P Y R A M I D+b_{9} D E V_{i}+b_{10} C V_{i}+b_{11} D E V_{i} * C V_{i} \\
& +b_{12} \text { fixed effects }+u_{i t}
\end{aligned}
$$

\begin{tabular}{|c|c|c|c|c|c|c|}
\hline & $\begin{array}{l}\text { Pooled } \\
\text { sample }\end{array}$ & Hong Kong & Malaysia & Singapore & $\begin{array}{l}\text { Firms hiring } \\
\text { big-five } \\
\text { auditors }\end{array}$ & $\begin{array}{l}\text { Firms hiring } \\
\text { local auditors }\end{array}$ \\
\hline Intercept & $\begin{array}{c}-2.44 * * * \\
(-9.29)\end{array}$ & $\begin{array}{c}-1.67 * * * \\
(-3.45)\end{array}$ & $\begin{array}{c}-4.00 * * * \\
(-7.58)\end{array}$ & $\begin{array}{c}-2.99 * * * \\
(-6.45)\end{array}$ & $\begin{array}{c}-2.27 * * * \\
(-6.92)\end{array}$ & $\begin{array}{c}-3.08 * * * \\
(-4.33)\end{array}$ \\
\hline Log(ASSETS) & $\begin{array}{c}0.59 * * * \\
(39.03)\end{array}$ & $\begin{array}{c}0.52 * * * \\
(21.37)\end{array}$ & $\begin{array}{c}0.65^{* * *} \\
(21.59)\end{array}$ & $\begin{array}{c}0.59 \text { *** } \\
(20.37)\end{array}$ & $\begin{array}{c}0.59 * * * \\
(31.55)\end{array}$ & $\begin{array}{c}0.64 * * * \\
(15.45)\end{array}$ \\
\hline ROA & $\begin{array}{c}-0.75 * * * \\
(-4.47)\end{array}$ & $\begin{array}{c}-0.69 * * * \\
(-3.80)\end{array}$ & $\begin{array}{l}-0.84^{*} \\
(-1.79)\end{array}$ & $\begin{array}{c}-0.81 \\
(-1.57)\end{array}$ & $\begin{array}{c}-1.14 * * * \\
(-5.67)\end{array}$ & $\begin{array}{c}-0.26 \\
(-0.61)\end{array}$ \\
\hline LEV & $\begin{array}{c}0.09 \\
(0.56)\end{array}$ & $\begin{array}{c}0.54 * * \\
(2.01)\end{array}$ & $\begin{array}{c}-0.08 \\
(-0.29)\end{array}$ & $\begin{array}{c}0.34 \\
(1.16)\end{array}$ & $\begin{array}{c}0.01 \\
(0.04)\end{array}$ & $\begin{array}{c}0.16 \\
(0.34)\end{array}$ \\
\hline $\mathrm{CA} / \mathrm{CL}$ & $\begin{array}{c}-0.03 \\
(-1.32)\end{array}$ & $\begin{array}{c}-0.01 \\
(-0.18)\end{array}$ & $\begin{array}{c}-0.08 * * \\
(-2.07)\end{array}$ & $\begin{array}{c}0.02 \\
(0.55)\end{array}$ & $\begin{array}{c}-0.03 \\
(-1.36)\end{array}$ & $\begin{array}{l}0.10^{*} \\
(1.70)\end{array}$ \\
\hline AR/ASSETS & $\begin{array}{c}1.04 * * * \\
(6.92)\end{array}$ & $\begin{array}{c}0.82 * * * \\
(3.72)\end{array}$ & $\begin{array}{c}1.03 * * * \\
(3.49)\end{array}$ & $\begin{array}{c}0.85 * * * \\
(2.99)\end{array}$ & $\begin{array}{c}0.93 * * * \\
(5.14)\end{array}$ & $\begin{array}{c}0.84 * * \\
(2.17)\end{array}$ \\
\hline INV/ASSETS & $\begin{array}{c}1.01^{* * * *} \\
(6.40)\end{array}$ & $\begin{array}{c}1.00 * * * \\
(4.51)\end{array}$ & $\begin{array}{c}0.40 \\
(1.19)\end{array}$ & $\begin{array}{c}1.45^{* * * *} \\
(4.76)\end{array}$ & $\begin{array}{c}1.38 * * * \\
(6.82)\end{array}$ & $\begin{array}{c}0.07 \\
(0.21)\end{array}$ \\
\hline GROUP & $\begin{array}{c}0.11 * * * \\
(2.36)\end{array}$ & $\begin{array}{c}0.01 \\
(0.10)\end{array}$ & $\begin{array}{l}0.17^{*} \\
(1.86)\end{array}$ & $\begin{array}{c}0.20 * * \\
(2.00)\end{array}$ & $\begin{array}{c}0.14 * * * \\
(2.54)\end{array}$ & $\begin{array}{c}-0.04 \\
(-0.37)\end{array}$ \\
\hline PYRAMID & $\begin{array}{c}-0.09 \\
(-1.52)\end{array}$ & $\begin{array}{c}-0.09 \\
(-0.67)\end{array}$ & $\begin{array}{c}0.02 \\
(0.15)\end{array}$ & $\begin{array}{c}-0.26 * * * \\
(-2.54)\end{array}$ & $\begin{array}{c}-0.13 \\
(-1.62)\end{array}$ & $\begin{array}{c}-0.09 \\
(-0.58)\end{array}$ \\
\hline DEV & $\begin{array}{c}0.30 * * \\
(1.96)\end{array}$ & $\begin{array}{l}0.47 * \\
(1.82)\end{array}$ & $\begin{array}{c}-1.02 * * * \\
(-2.76)\end{array}$ & $\begin{array}{c}0.91 * * * \\
(2.71)\end{array}$ & $\begin{array}{c}0.40 * * \\
(2.11)\end{array}$ & $\begin{array}{c}-0.17 \\
(-0.39)\end{array}$ \\
\hline $\mathrm{CV}$ & $\begin{array}{c}0.21 \\
(1.48)\end{array}$ & $\begin{array}{c}0.12 \\
(0.36)\end{array}$ & $\begin{array}{c}0.17 \\
(0.58)\end{array}$ & $\begin{array}{c}0.28 \\
(1.42)\end{array}$ & $\begin{array}{c}0.18 \\
(0.96)\end{array}$ & $\begin{array}{c}0.18 \\
(0.57)\end{array}$ \\
\hline $\mathrm{DEV} * \mathrm{CV}$ & $\begin{array}{l}-0.31 * \\
(-1.78)\end{array}$ & $\begin{array}{l}-0.47^{*} \\
(-1.69)\end{array}$ & $\begin{array}{c}1.14 * * * \\
(2.71)\end{array}$ & $\begin{array}{c}-1.06^{* * * *} \\
(-2.63)\end{array}$ & $\begin{array}{l}-0.40^{*} \\
(-1.85)\end{array}$ & $\begin{array}{c}0.14 \\
(0.29)\end{array}$ \\
\hline adjusted R2 & 0.68 & 0.54 & 0.64 & 0.56 & 0.67 & 0.74 \\
\hline Observations & 1304 & 534 & 369 & 401 & 889 & 179 \\
\hline
\end{tabular}




\section{William Davidson Institute Working Paper 400}

$L A F_{i t}=$ natural $\log$ of total audit fees at year $\mathrm{t} ; S I Z E_{i t}=$ natural logarithm of total assets in millions of U.S. dollars at year $\mathrm{t} ; R O A_{i t}=$ net income divided by total assets at year $\mathrm{t} ; L E V_{i t}=$ long-term debt divided by total assets at year $\mathrm{t}$; $C A C L_{i t}=$ current assets divided current liabilities at year $\mathrm{t} ; A R_{i t}=$ accounts receivable divided total assets at year $\mathrm{t}$; $I N V_{i t}=$ inventory divided total assets at year $\mathrm{t} ; G R O U P_{i}=1$ when the client firm is a member of a corporate group, and 0 otherwise; $P Y R A M I D_{i}=1$ when the client firm is controlled by an affiliated firm through a stock pyramid, and 0 otherwise; $D E V_{i}=1$ when the percentage of voting rights possessed by the largest ultimate owner of the firm exceeds the median in the corresponding economy, and 0 otherwise; $C V_{i}=$ the ratio of cash flow rights to voting rights of the largest ultimate owner; Fixed effects $=$ dummy variables controlling for fixed effects of industries, calendar years and economies. For simplicity, results for the fixed effects are not reported. ***, **, and $*$ denote $1 \%, 5 \%$ and $10 \%$ 2-tailed test. 


\section{Table 9}

Ordinary Least Squares Regression Results of Audit Fee by Profitability, Leverage, and Firm Size Partitions

$$
\begin{aligned}
L A F_{i t}= & b_{0}+b_{1} \log \left(S I Z E_{i t}\right)+b_{2} R O A_{i t}+b_{3} L E V_{i t}+b_{4} C A C L_{i t}+b_{5} A R_{i t}+b_{6} I N V_{i t} \\
& +b_{7} \text { GROUP }+b_{8} \text { PYRAMID }+b_{9} D E V_{i}+b_{10} C V_{i}+b_{11} D E V_{i} * C V_{i} \\
& +b_{12} \text { fixed effects }+u_{i t}
\end{aligned}
$$

\begin{tabular}{|c|c|c|c|c|c|c|}
\hline & $\begin{array}{l}\text { Low profit } \\
\text { firms }\end{array}$ & $\begin{array}{l}\text { High profit } \\
\text { firms }\end{array}$ & $\begin{array}{c}\text { High } \\
\text { leverage } \\
\text { firms }\end{array}$ & $\begin{array}{c}\text { Low } \\
\text { leverage } \\
\text { firms }\end{array}$ & Small firms & Large firms \\
\hline Intercept & $\begin{array}{c}-2.13 * * * \\
(-5.58)\end{array}$ & $\begin{array}{c}-2.53 * * * \\
(-6.65)\end{array}$ & $\begin{array}{c}-2.02 * * * \\
(-5.40)\end{array}$ & $\begin{array}{c}-2.96 * * * \\
(-8.00)\end{array}$ & $\begin{array}{c}-2.10 * * * \\
(-5.03)\end{array}$ & $\begin{array}{c}-3.07 * * * \\
(-5.56)\end{array}$ \\
\hline $\log ($ ASSETS $)$ & $\begin{array}{c}0.60 * * * \\
(27.34)\end{array}$ & $\begin{array}{c}0.58^{* * * *} \\
(26.62)\end{array}$ & $\begin{array}{c}0.60 * * * \\
(26.47)\end{array}$ & $\begin{array}{c}0.61 * * * \\
(29.47)\end{array}$ & $\begin{array}{c}0.56 * * * \\
(18.01)\end{array}$ & $\begin{array}{c}0.65 * * * \\
(19.05)\end{array}$ \\
\hline ROA & $\begin{array}{c}-0.80 * * * \\
(-3.03)\end{array}$ & $\begin{array}{l}-0.48^{*} \\
(-1.66)\end{array}$ & $\begin{array}{l}-0.43^{*} \\
(-1.77)\end{array}$ & $\begin{array}{c}-1.07 * * * \\
(-4.60)\end{array}$ & $\begin{array}{c}-0.48 * * * \\
(-2.73)\end{array}$ & $\begin{array}{c}-1.41 * * * \\
(-3.23)\end{array}$ \\
\hline LEV & $\begin{array}{l}-0.26 \\
(-1.40)\end{array}$ & $\begin{array}{c}0.74 * * * \\
(2.84)\end{array}$ & $\begin{array}{l}-0.08 \\
(-0.44)\end{array}$ & $\begin{array}{l}-0.25 \\
(-0.66)\end{array}$ & $\begin{array}{c}0.19 \\
(1.05)\end{array}$ & $\begin{array}{c}-0.22 \\
(-0.89)\end{array}$ \\
\hline $\mathrm{CA} / \mathrm{CL}$ & $\begin{array}{c}-0.00 \\
(-0.08)\end{array}$ & $\begin{array}{c}-0.03 \\
(-1.26)\end{array}$ & $\begin{array}{c}-0.08 \\
(-1.63)\end{array}$ & $\begin{array}{c}0.00 \\
(0.01)\end{array}$ & $\begin{array}{c}-0.08 * * * \\
(-3.27)\end{array}$ & $\begin{array}{c}0.04 \\
(1.31)\end{array}$ \\
\hline AR/ASSETS & $\begin{array}{c}1.50 * * * \\
(6.75)\end{array}$ & $\begin{array}{c}0.63 * * * \\
(3.06)\end{array}$ & $\begin{array}{c}0.61 * * * * \\
(2.90)\end{array}$ & $\begin{array}{c}1.21 * * * \\
(4.39)\end{array}$ & $\begin{array}{c}0.46 * * * \\
(2.65)\end{array}$ & $\begin{array}{c}1.89 * * * \\
(6.62)\end{array}$ \\
\hline INV/ASSETS & $\begin{array}{c}0.37 \\
(1.62)\end{array}$ & $\begin{array}{c}1.56^{* * * *} \\
(7.17)\end{array}$ & $\begin{array}{c}0.33 \\
(1.52)\end{array}$ & $\begin{array}{c}1.94 * * * \\
(7.12)\end{array}$ & $\begin{array}{c}0.89 * * * \\
(4.89)\end{array}$ & $\begin{array}{c}1.24 * * * \\
(4.26)\end{array}$ \\
\hline GROUP & $\begin{array}{l}0.01^{*} \\
(0.08)\end{array}$ & $\begin{array}{c}0.16^{* * *} \\
(2.62)\end{array}$ & $\begin{array}{l}0.12^{*} \\
(1.93)\end{array}$ & $\begin{array}{l}0.10^{*} \\
(1.65)\end{array}$ & $\begin{array}{c}0.04 \\
(0.72)\end{array}$ & $\begin{array}{c}0.09 \\
(1.23)\end{array}$ \\
\hline PYRAMID & $\begin{array}{l}-0.17 * * \\
(-1.94)\end{array}$ & $\begin{array}{c}-0.03 \\
(-0.38)\end{array}$ & $\begin{array}{l}-0.19 * * \\
(-2.31)\end{array}$ & $\begin{array}{c}0.03 \\
(0.32)\end{array}$ & $\begin{array}{c}0.01 \\
(0.16)\end{array}$ & $\begin{array}{l}-0.16 \\
(-1.55)\end{array}$ \\
\hline DEV & $\begin{array}{l}0.38^{*} \\
(1.67)\end{array}$ & $\begin{array}{c}0.27 \\
(1.24)\end{array}$ & $\begin{array}{l}0.50 * * \\
(2.26)\end{array}$ & $\begin{array}{c}0.11 \\
(0.50)\end{array}$ & $\begin{array}{c}0.49 * * * \\
(2.54)\end{array}$ & $\begin{array}{c}0.06 \\
(0.23)\end{array}$ \\
\hline $\mathrm{CV}$ & $\begin{array}{c}0.00 \\
(0.02)\end{array}$ & $\begin{array}{c}0.31 \\
(1.43)\end{array}$ & $\begin{array}{l}0.33^{*} \\
(1.78)\end{array}$ & $\begin{array}{c}0.20 \\
(0.93)\end{array}$ & $\begin{array}{c}0.31 \\
(1.62)\end{array}$ & $\begin{array}{c}0.19 \\
(0.91)\end{array}$ \\
\hline $\mathrm{DEV} * \mathrm{CV}$ & $\begin{array}{c}-0.38 \\
(-1.49)\end{array}$ & $\begin{array}{l}-0.28 \\
(-1.14)\end{array}$ & $\begin{array}{c}-0.61 * * * \\
(-2.45)\end{array}$ & $\begin{array}{c}-0.03 \\
(-0.13)\end{array}$ & $\begin{array}{c}-0.47 * * \\
(-2.14)\end{array}$ & $\begin{array}{l}-0.20 \\
(-0.71)\end{array}$ \\
\hline Adjusted R2 & 0.70 & 0.68 & 0.65 & 0.73 & 0.67 & 0.56 \\
\hline Observations & 591 & 713 & 658 & 646 & 740 & 564 \\
\hline
\end{tabular}




\section{William Davidson Institute Working Paper 400}

$L A F_{i t}=$ natural $\log$ of total audit fees at year t; $S I Z E_{i t}=$ natural logarithm of total assets in millions of U.S. dollars at year $\mathrm{t} ; R O A_{i t}=$ net income divided by total assets at year $\mathrm{t} ; L E V_{i t}=$ long-term debt divided by total assets at year $\mathrm{t} ; C A C L_{i t}=$ current assets divided current liabilities at year $\mathrm{t} ; A R_{i t}=$ accounts receivable divided total assets at year $\mathrm{t} ; I N V_{i t}=$ inventory divided total assets at year $\mathrm{t}$; GROUP $_{i}=1$ when the client firm is a member of a corporate group, and 0 otherwise; $P Y R A M I D_{i}=1$ when the client firm is controlled by an affiliated firm through a stock pyramid, and 0 otherwise; $D E V_{i}$ $=1$ when the percentage of voting rights possessed by the largest ultimate owner of the firm exceeds the median in the corresponding economy, and 0 otherwise; $C V_{i}=$ the ratio of cash flow rights to voting rights of the largest ultimate owner; Fixed effects $=$ dummy variables controlling for fixed effects of industries, calendar years and economies. For simplicity, results for the fixed effects are not reported. The sample is classified into high (low) subgroup when the partitioning variable of that year is higher than its corresponding three-year median of the economy. The partitioning variable for profitability is net income over total assets, for leverage is total liabilities over total assets and firm size is total assets. $* * *, * *$, and $*$ denote $1 \%, 5 \%$ and $10 \%$ 2-tailed test. 
Table 10

Logit Regression Results of Audit Opinion

$$
\begin{aligned}
\text { OPINION }_{i t}= & b_{0}+b_{1} \log \left(\text { SIZE }_{i t}\right)+b_{2} R O A_{i t}+b_{3} L E V_{i t}+b_{4} C A C L_{i t}+b_{5} A R_{i t} \\
& +b_{6} I N V_{i t}+b_{7} \text { GROUP }+b_{8} \text { PYRAMID }+b_{9} D C V_{i} \\
& +b_{10} D C V_{i} * R O A_{i t}+\text { fixed effects }+u_{i t}
\end{aligned}
$$

\begin{tabular}{|c|c|c|c|}
\hline & Pooled sample & $\begin{array}{c}\text { Firms hiring } \\
\text { big-five auditors }\end{array}$ & $\begin{array}{l}\text { Firms hiring } \\
\text { local auditors }\end{array}$ \\
\hline Intercept & $\begin{array}{c}-5.35 * * * \\
(-2.68)\end{array}$ & $\begin{array}{l}-4.52 * \\
(-1.73)\end{array}$ & $\begin{array}{c}-5.72 \\
(-0.67)\end{array}$ \\
\hline SIZE & $\begin{array}{c}0.08 \\
(0.56)\end{array}$ & $\begin{array}{c}0.01 \\
(0.06)\end{array}$ & $\begin{array}{c}-0.59 \\
(-1.16)\end{array}$ \\
\hline ROA & $\begin{array}{c}-6.73 * * * \\
(-4.96)\end{array}$ & $\begin{array}{c}-6.26 * * * \\
(-3.50)\end{array}$ & $\begin{array}{c}-19.98 * * \\
(-2.02)\end{array}$ \\
\hline LEV & $\begin{array}{l}-1.11 \\
(-1.23)\end{array}$ & $\begin{array}{c}-1.63 \\
(-1.36)\end{array}$ & $\begin{array}{l}7.64 * \\
(1.84)\end{array}$ \\
\hline $\mathrm{CA} / \mathrm{CL}$ & $\begin{array}{c}-0.03 \\
(-0.67)\end{array}$ & $\begin{array}{c}-0.02 \\
(-0.43)\end{array}$ & $\begin{array}{c}-0.10 \\
(-0.58)\end{array}$ \\
\hline AR/ASSETS & $\begin{array}{l}-3.94 * * \\
(-2.30)\end{array}$ & $\begin{array}{l}-3.48^{*} \\
(-1.72)\end{array}$ & $\begin{array}{c}-4.44 \\
(-0.84)\end{array}$ \\
\hline INV/ASSETS & $\begin{array}{c}-0.84 \\
(-0.62)\end{array}$ & $\begin{array}{c}0.21 \\
(0.11)\end{array}$ & $\begin{array}{c}3.70 \\
(1.17)\end{array}$ \\
\hline GROUP & $\begin{array}{c}-1.00 * * * \\
(-2.41)\end{array}$ & $\begin{array}{c}-1.61 * * * \\
(-2.75)\end{array}$ & $\begin{array}{l}-2.37 * \\
(-1.89)\end{array}$ \\
\hline PYRAMID & $\begin{array}{c}0.51 \\
(0.85)\end{array}$ & $\begin{array}{c}-0.19 \\
(-0.24)\end{array}$ & $\begin{array}{l}2.81^{*} \\
(1.79)\end{array}$ \\
\hline $\mathrm{DCV}$ & $\begin{array}{c}-0.69 \\
(-1.02)\end{array}$ & $\begin{array}{c}0.42 \\
(0.54)\end{array}$ & $\begin{array}{c}-8.63 \\
(-0.17)\end{array}$ \\
\hline $\mathrm{DCV} * \mathrm{ROA}$ & $\begin{array}{c}-9.86 * * * \\
(-2.76)\end{array}$ & $\begin{array}{c}-9.68 * * * \\
(-2.69)\end{array}$ & $\begin{array}{c}0.63 \\
(0.00)\end{array}$ \\
\hline Pseudo R2 & 0.07 & 0.06 & 0.14 \\
\hline Observations & 2335 & 1758 & 577 \\
\hline Chi-square & 173.55 & 115.39 & 96.43 \\
\hline Degree of Freedom & 25 & 25 & 25 \\
\hline P-value & 0.0001 & 0.0001 & 0.0001 \\
\hline
\end{tabular}


$O P I N I O N_{i t}=1$ when it is a modified opinion, and 0 otherwise; $S I Z E_{i t}=$ natural logarithm of total assets in millions of U.S. dollars at year $\mathrm{t} ; R O A_{i t}=$ net income divided by total assets at year $\mathrm{t}$; $L E V_{i t}=$ long-term debt divided by total assets at year $\mathrm{t} ; C A C L_{i t}=$ current assets divided current liabilities at year $\mathrm{t} ; A R_{i t}=$ accounts receivable divided total assets at year $\mathrm{t}$; $I N V_{i t}=$ inventory divided total assets at year $\mathrm{t}$; GROUP $P_{i}=1$ when the client firm is a member of a corporate group, and 0 otherwise; $P Y R A M I D_{i}=1$ when the client firm is in the bottom of the pyramid, and 0 otherwise; $D C V_{i}=1$ when the ratio of cash flow rights to voting rights of the largest ultimate owner is less than 1, and 0 otherwise; Fixed effects = dummy variables controlling for fixed effects of industries, calendar years and economies; For simplicity, results for the fixed effects are not reported. $* * *, * *$, and $*$ denote $1 \%, 5 \%$ and $10 \% 2$-tailed test. 


\section{DAVIDSON INSTITUTE WORKING PAPER SERIES - Most Recent Papers}

The entire Working Paper Series is available at: www.wdi.bus.umich.edu

CURRENT AS OF 10/30/01

\begin{tabular}{|c|c|c|}
\hline Publication & Authors & Date \\
\hline $\begin{array}{l}\text { No. 400: Do External Auditors Perform a Corporate Governance Role in } \\
\text { Emerging Markets? Evidence from East Asia }\end{array}$ & Joseph P. H. Fan and T.J. Wong & Oct. 2001 \\
\hline $\begin{array}{l}\text { No. 399: Financial Conditions and Investment during the Transition: } \\
\text { Evidence from Czech Firms }\end{array}$ & Lubomír Lízal and Jan Svejnar & Oct. 2001 \\
\hline $\begin{array}{l}\text { No. 398: Accessible Pareto-Improvements: Using Market Information to } \\
\text { Reform Inefficiencies }\end{array}$ & Michael Mandler & May 2001 \\
\hline No. 397: The Making of an Integrated National Grain Market in China & Wubiao Zhou & Oct. 2001 \\
\hline No. 396: Corruption and Resource Allocation: Evidence from China & Wei Li & June 2001 \\
\hline $\begin{array}{l}\text { No. 395: Government Shareholding and the Value of China's Modern } \\
\text { Firms }\end{array}$ & Lihui Tian & Apr. 2001 \\
\hline No. 394: Labor Hoarding in Russia: Where Does it Come from? & $\begin{array}{l}\text { Rouslan Koumakhov amd Boris } \\
\text { Najman }\end{array}$ & June 2000 \\
\hline $\begin{array}{l}\text { No. 393: Ownership Structure, Corporate Governance, And Firm Value: } \\
\text { Evidence from the East Asian Financial Crisis }\end{array}$ & Michael Lemmons and Karl Lins & Apr. 2001 \\
\hline No. 392: Marshall and Labour Demand in Russia: Going Back to Basics & $\begin{array}{l}\text { Jozef Konings and Hartmut } \\
\text { Lehmann }\end{array}$ & Aug. 2001 \\
\hline No. 391: Economic Transition and Elections in Poland & $\begin{array}{l}\text { John E. Jackson, Jacek Klich, and } \\
\text { Krystyna Poznańska }\end{array}$ & June 2001 \\
\hline $\begin{array}{l}\text { No. 390: Effects of Bank Insolvency and Strategic Uncertainty on } \\
\text { Corporate Restructuring in Transition Economies }\end{array}$ & Christa Hainz & Aug. 2001 \\
\hline No. 389: Mark-Up Pricing In Bulgarian Manufacturing & $\begin{array}{l}\text { Rumen Dobrinsky, Boyko } \\
\text { Nikolov, and Nikolay Markov }\end{array}$ & June 2001 \\
\hline $\begin{array}{l}\text { No. } 388 \text { Globalization and Fir } \\
\text { Evidence from Emerging Eco }\end{array}$ & $\begin{array}{l}\text { Sergio Schmukler and Esteban } \\
\text { Vesperoni }\end{array}$ & May 2001 \\
\hline $\begin{array}{l}\text { No. } 387 \text { The Distributional Impacts of Indonesia's Financial Crisis on } \\
\text { Household Welfare: A "Rapid Response" Methodology }\end{array}$ & $\begin{array}{l}\text { Jed Friedman and James } \\
\text { Levinsohn }\end{array}$ & Sept. 2001 \\
\hline $\begin{array}{l}\text { No. } 386 \text { Corporate Financial Policies and Performance Prior to Currency } \\
\text { Crises }\end{array}$ & $\begin{array}{l}\text { Arturo Bris, Yrjö Koskinen, and } \\
\text { Vicente Pons }\end{array}$ & June 2001 \\
\hline No. 385 Ownership and Productive Efficiency: Evidence from Estonia & Derek C. Jones and Niels Mygind & Aug. 2001 \\
\hline $\begin{array}{l}\text { No. } 384 \text { Forthcoming in: Journal of Economic Perspectives, } \\
\text { "Institutional Determinants of Labor Reallocation in Transition" Vol. } \\
\text { 16, No. 2, Feb. } 2002 \text {. }\end{array}$ & Tito Boeri and Katherine Terrell & June 2001 \\
\hline $\begin{array}{l}\text { No. } 383 \text { Deindustrialisation and Structural Change During the Post- } \\
\text { Communist Transition }\end{array}$ & $\begin{array}{l}\text { Tomasz Mickiewicz and Anna } \\
\text { Zalewska }\end{array}$ & June 2001 \\
\hline No. 382 Markets and Growth & Štěpán Jurajda and Janet Mitchell & July 2001 \\
\hline $\begin{array}{l}\text { No. } 381 \text { Labor Market Discrimination During Post-Communist } \\
\text { Transition: A Monopsony Approach to the Status of Latvia's Russian } \\
\text { Minority }\end{array}$ & Robert S. Chase & Sept. 2000 \\
\hline No. 380 Dollarization of Liabilities in Non-tradable Goods Sector & Frédéric Chabellard & June 2001 \\
\hline $\begin{array}{l}\text { No. } 379 \text { Lessons from the Russian Meltdown: The Economics of Soft } \\
\text { Legal Constraints }\end{array}$ & Enrico Perotti & Mar. 2001 \\
\hline No. 378 Effective Tax Rates in Transition & Vlad Ivanenko & May 2001 \\
\hline $\begin{array}{l}\text { No. } 377 \text { Some Explanations for Changes in the Distribution of } \\
\text { Household Income in Slovakia: } 1988 \text { and } 1996\end{array}$ & $\begin{array}{l}\text { Thesia Garner and Katherine } \\
\text { Terrell }\end{array}$ & May 2001 \\
\hline $\begin{array}{l}\text { No. } 376 \text { Competition and Enterprise Performance in Transition } \\
\text { Economies: Evidence from a Cross-country Survey }\end{array}$ & $\begin{array}{l}\text { Wendy Carlin, Steven Fries, } \\
\text { Mark Schaffer and Paul Seabright }\end{array}$ & May 2001 \\
\hline $\begin{array}{l}\text { No. } 375 \text { Why More is Actually Less: New Interpretations of China's } \\
\text { Labor-Intensive FDI }\end{array}$ & Yasheng Huang & May 2001 \\
\hline No. 374 Economic Fragmentation and FDI in China & Yasheng Huang & May 2001 \\
\hline
\end{tabular}

